Article

\title{
Marine Microalgae Biomolecules and Their Adhesion Capacity to Salmonella enterica sv. Typhimurium
}

\author{
Tatiane Winkler Marques Machado ${ }^{1,2,+}$, Jenifer Mota Rodrigues $2,3,+\left(\mathbb{C}\right.$, Tatiana Rojo Moro ${ }^{1,2} \oplus$, \\ Maria Eugênia Rabello Duarte ${ }^{2, *}$ and Miguel Daniel Noseda ${ }^{2, * \mathbb{D}}$ \\ 1 Postgraduate Program in Sciences (Biochemistry), Federal University of Paraná (UFPR), \\ Curitiba 81531-980, Paraná, Brazil; tatiwinkler@gmail.com (T.W.M.M.); tatiana.rmoro@gmail.com (T.R.M.) \\ 2 Biochemistry and Molecular Biology Dept., UFPR, Av. Cel. Francisco H. dos Santos, 100, P.O. Box 19046, \\ Curitiba 81531-980, Paraná, Brazil; jeni.mota.r@gmail.com \\ 3 Postgraduate Program in Bioprocesses and Biotechnology Engineering, UFPR, \\ Curitiba 81531-990, Paraná, Brazil \\ * Correspondence: eugenia.duarte@pq.cnpq.br (M.E.R.D.); mdn@ufpr.br (M.D.N.) \\ + These authors equally contributed to this work.
}

Received: 5 March 2020; Accepted: 16 March 2020; Published: 25 March 2020

\begin{abstract}
Different molecules have been tested as analog receptors due to their capacity to bind bacteria and prevent cell adhesion. By using in vitro assays, the present study characterized the aqueous and alkaline extracts from microalgae Pavlova lutheri and Pavlova gyrans and evaluated the capacity of these extracts to adhere to enterobacteria (Salmonella Typhimurium). The aqueous and alkaline extracts of both species were fractionated via freeze-thawing, giving rise to soluble and insoluble (precipitate) fractions in cold water. The obtained fractions were studied using thermogravimetric, methylation analyses, and using $1 \mathrm{D}$ and $2 \mathrm{D}$ NMR techniques. The cold-water-soluble fractions obtained from the aqueous extracts were mainly composed of highly branched $(1 \rightarrow 3),(1 \rightarrow 6)-\beta$-glucans, whereas the cold-water-precipitate fractions were constituted by $(1 \rightarrow 3)-\beta$-glucans. The alkaline extract fractions showed similar compositions with a high protein content, and the presence of glycosides (sulfoquinovosylglycerol (SQG), digalactosylglycerol (DGG)), and free fatty acids. The linear $(1 \rightarrow 3)$ - $\beta$-glucans and the alkaline extract fractions showed an adhesion capacity toward Salmonella. The chemical composition of the active fractions suggested that the presence of three-linked $\beta$-glucose units, as well as microalgal proteins and glycosides, could be important in the adhesion process. Therefore, these microalgal species possess a high potential to serve as a source of anti-adhesive compounds.
\end{abstract}

Keywords: microalgae; Pavlova; $\beta$-glucans; glycosides; adhesion capacity; enterobacteria

\section{Introduction}

Microalgae are photosynthetic microorganisms capable of producing a wide variety of biomolecules in accordance with the division or class to which they belong. The large biodiversity encompasses about $200,000-800,000$ species, of which only 50,000 have been taxonomically defined and over 15,000 novel compounds have so far been associated with algae biomass, including carotenoids, sterols, phycobiliproteins, phycotoxins, and polysaccharides [1-3]. Phylum Haptophyta comprises two classes, Coccolithophyceae and Pavlovophyceae [4], where the latter includes the two marine species under study, Pavlova lutheri and Pavlova gyrans. Since they can be easily grown, quickly ingested and digested, and exhibit a high nutritional value, these species, as well as some other microalgae, are widely used as raw material in the aquaculture of fish, mollusks, and crustaceans [5-7]. All these characteristics have also aroused the interest of the biotechnology sector for the potential use of these microorganisms in nutritional and pharmaceutical bioproducts [8]. 
Polysaccharides and oligosaccharides from different microalgal sources have widely diverse chemical structures and are known to have multiple biological activities $[9,10]$. Numerous investigations have suggested that some types of carbohydrates can avoid enteric infections by inhibiting adhesion of enteropathogens to the host tissue [11-15]. Adhesion is the first step in a bacterial infection process and it is mediated via adhesins expressed by bacteria that recognize and adhere to ligand-like carbohydrates located on the surface of host epithelial cells [16]. Thus, carbohydrates can act as analog receptors, mimicking the host receptors and participating in binding with specific bacterial adhesins. Therefore, anti-adherence therapies act to reduce infections and diseases, as well as the risk of transmission via the food chain. In addition, its application acts as an alternative to the inappropriate and excessive use of antibiotics with the added benefit of reducing selective pressure since pathogens are not killed, they are only impeded from attaching to host cells [17].

Commercial products with anti-adhesive properties that are derived from yeast cell walls and contain mannose have been sold worldwide for a long time and employed in animal feed to bind pathogens and prevent bacterial adhesion $[18,19]$. Few studies examining the anti-adhesive properties of polysaccharides derived from microalgae are available in the literature. Guzman-Murillo and Ascencio [20] reported that sulfated exopolysaccharides from Tetraselmis sp., Neochloris oleoabundans, and Phaeodactylum tricornutum caused a 50\% inhibition of adhesion of Helicobacter pylori to HeLa S3 cells. According to Loke et al. [21], polysaccharides obtained from Spirulina and Chlorella were capable of preventing H. pylori from binding to gastric mucin. Thus, the present study aimed to obtain and characterize aqueous and alkaline extracts from microalgae P. lutheri and P. gyrans and evaluate, using an in vitro assay, the ability of these extracts to adhere to enterobacteria Salmonella enterica sv. Typhimurium.

\section{Materials and Methods}

\subsection{Algae Culture Conditions}

Haptophyte species P. gyrans (UTEX LB 992, Culture Collection of Algal at The University of Texas, Austin, TX, USA) and P. lutheri (Elizabeth Aidar Microalgae Collection, Fluminense Federal University, Niteroi, RJ, Brazil) were cultivated in Erlenmeyer flasks (2 L) with Guillard f/2 culture medium [22]. The culture medium was prepared using filtered seawater or synthetic seawater $\left(30 \mathrm{~g} \cdot \mathrm{L}^{-1}\right)$, sterilized at $120^{\circ} \mathrm{C}$ for $15 \mathrm{~min}$ before inoculation. Microalgal growth was performed at $18-20^{\circ} \mathrm{C}$ under constant light $\left(100 \mu \mathrm{mol} \cdot \mathrm{m}^{-2} \cdot \mathrm{s}^{-1}\right)$, and the air was supplied at a flow rate of $3 \mathrm{~L} \cdot \mathrm{min}^{-1}$ (without supplementary $\mathrm{CO}_{2}$ ). After fourteen days, we removed the microalgal biomass using centrifugation $\left(10,000 \times g, 20 \mathrm{~min}, 4^{\circ} \mathrm{C}\right)$ and lyophilized it for further analysis ( 0.4 and $0.7 \mathrm{~g} \cdot \mathrm{L}^{-1}$ yield for P. gyrans and P. lutheri, respectively).

\subsection{Microalgae Extraction}

Sequential extractions were performed for both species, P. gyrans and P. lutheri, where the procedures are summarized in Figure 1. Dry biomasses were submitted to aqueous extraction $\left(20 \mathrm{~g} \cdot \mathrm{L}^{-1}\right)$ under magnetic stirring at $80^{\circ} \mathrm{C}$ for $2 \mathrm{~h}(2 \times)$, followed by alkaline extraction with $0.5 \mathrm{M} \mathrm{NaOH}\left(20 \mathrm{~g} \cdot \mathrm{L}^{-1}\right)$ and $\mathrm{NaBH}_{4}\left(5 \%\right.$ w/w) at $80^{\circ} \mathrm{C}$ for $2 \mathrm{~h}$. After each extraction, the residual biomasses were removed via centrifugation $\left(12,000 \times g, 20 \mathrm{~min}, 4^{\circ} \mathrm{C}\right)$ and submitted to the next extraction. Combined aqueous extracts and alkaline extracts (after neutralization with $0.5 \mathrm{M} \mathrm{HCl}$ ) were concentrated and submitted to ethanol precipitation $(\mathrm{EtOH} 99 \%, 3: 1 \mathrm{v} / \mathrm{v})$ at $4{ }^{\circ} \mathrm{C}$ overnight. The precipitates obtained via centrifugation $(12,000 \times$ $\mathrm{g}, 15 \mathrm{~min}, 4^{\circ} \mathrm{C}$ ) were dissolved in water and submitted to fractionation using freeze-thawing [23]. The fractions that were soluble in cold water (W-s and A-s) were separated from the insoluble fractions (W-p and A-p) using centrifugation $\left(12,000 \times g, 20 \mathrm{~min}, 4^{\circ} \mathrm{C}\right)$. All the fractions obtained were dialyzed (1-2 kDa molecular weight (MW) cut-off for aqueous fractions and 12-14 kDa MW cut-off for alkaline fractions; Spectra/Por Dialysis Membrane, Repligen Corporation, Rancho Dominguez, CA, USA) against distilled water and freeze-dried. 


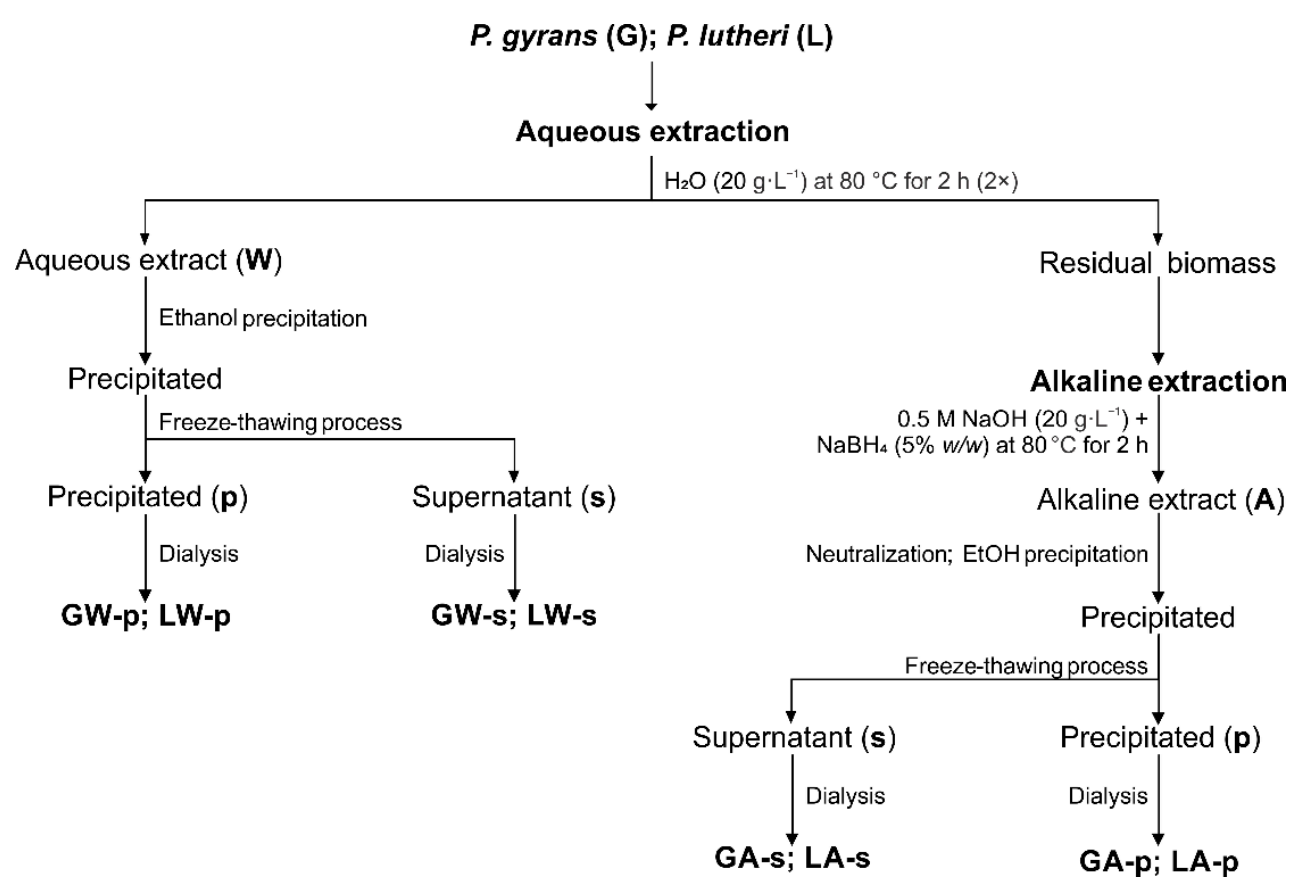

Figure 1. Extraction sequence and fractionation of crude extracts from microalgae P. gyrans and P. lutheri. $\mathrm{G}$ and L fractions correspond to P. gyrans and P. lutheri, respectively; $\mathrm{W}$ and A correspond to aqueous and alkaline extracts, respectively; and $\mathrm{p}$ and s correspond to precipitated and supernatant extracts, respectively.

\subsection{Characterization of Microalgal Extracts and Fractions}

\subsubsection{General Methods}

The total carbohydrate and protein contents were determined according to previously reported methods [24,25] using glucose and bovine serum albumin as standards, respectively. Thermogravimetric analyses (TGA) were carried out using a thermal analyzer STA 449 F3-Jupiter (NETZSCH-Gerätebau GmbH, Selb, BY, Germany) with an alumina sample pan, a sample mass of $15.0 \mathrm{mg}$, and under a nitrogen atmosphere with a temperature program from $20-800{ }^{\circ} \mathrm{C}$ at the heating rate of $10^{\circ} \mathrm{C} \cdot \mathrm{min}^{-1}$. For the monosaccharide composition, fractions were hydrolyzed $(2 \mathrm{M}$ TFA (trifluoroacetic acid), $\left.100{ }^{\circ} \mathrm{C}, 2 \mathrm{~h}\right)$, reduced with $\mathrm{NaBH}_{4}$ and acetylated with $\mathrm{Ac}_{2} \mathrm{O}\left(120^{\circ} \mathrm{C}, 1 \mathrm{~h}\right)$. The resulting alditol acetate derivatives were analyzed using gas chromatography-mass spectrometry (GC-MS) and identified using their typical electron-impact breakdown profiles and retention times [26]. GC-MS analyses were performed using a Varian 3800 gas chromatograph (Agilent Technologies Inc., Santa Clara, CA, USA) connected to a Varian Saturn 2000R ITD mass spectrometer with an Agilent J\&W DB-225 capillary column $\left(30 \mathrm{~m} \times 0.25 \mathrm{~mm}\right.$ i.d.), programmed to heat up from 50 to $220^{\circ} \mathrm{C}$ at $40^{\circ} \mathrm{C} \cdot \mathrm{min}^{-1}$, and using helium as the carrier gas $\left(1 \mathrm{~mL} \cdot \mathrm{min}^{-1}\right)$.

\subsubsection{Methylation Analyses}

Methylation analysis was carried out in accordance with Ciucanu and Kerek [27]. Polysaccharides $(5 \mathrm{mg})$ were dissolved in $\mathrm{Me}_{2} \mathrm{SO}(1 \mathrm{~mL})$, followed by the addition of powdered $\mathrm{NaOH}(30 \mathrm{mg})$. After $30 \mathrm{~min}$, under magnetic stirring at $25^{\circ} \mathrm{C}, \mathrm{CH}_{3} \mathrm{I}(0.2 \mathrm{~mL})$ was added, and the reaction remained for another $30 \mathrm{~min}$. Except for the $\mathrm{Me}_{2} \mathrm{SO}$ addition, the above-mentioned process was repeated twice, and the reaction was interrupted via the addition of water and neutralized with $50 \%(v / v)$ aq. AcOH. Methylation products were dialyzed against distilled water, freeze-dried, and submitted to two more steps of methylation in the same way as described above. Products $(1.5 \mathrm{mg})$ were then hydrolyzed with $90 \%(v / v)$ aq. formic acid $(0.5 \mathrm{~mL})$ at $100{ }^{\circ} \mathrm{C}$ for $6 \mathrm{~h}$ and then with $2 \mathrm{M}$ TFA $(0.5 \mathrm{~mL})$ for $2 \mathrm{~h}$ at $80^{\circ} \mathrm{C}$ [28]. The resulting mixtures of partially $\mathrm{O}$-methylated aldoses were reduced with $\mathrm{NaBD}_{4}$ and acetylated as described above for the monosaccharide composition to give a mixture 
of partially $O$-methylated alditol acetates, which were analyzed using GC-MS and identified using their typical electron-impact breakdown profiles and retention times [26,29].

\subsubsection{Nuclear Magnetic Resonance Spectroscopy (NMR)}

NMR spectroscopic analyses were performed using a Bruker AVANCE III 400 NMR spectrometer (Bruker BioSpin Corporation, Billerica, MA, USA) equipped with a 5-mm inverse probe, operating at 400.13 and $100.63 \mathrm{MHz}$ for ${ }^{1} \mathrm{H}$ and ${ }^{13} \mathrm{C}$, respectively, at $70{ }^{\circ} \mathrm{C} .{ }^{1} \mathrm{H},{ }^{13} \mathrm{C}$, and ${ }^{13} \mathrm{C}-\mathrm{DEPT}-135$ (Distortionless Enhancement by Polarization Transfer $135^{\circ}$ ) acquisition parameters were previously reported [30]. $2 \mathrm{D}{ }^{1} \mathrm{H} /{ }^{13} \mathrm{C}$ HSQC (Heteronuclear Single Quantum Coherence) experiments were performed using pulse programs supplied by the Bruker manual. Samples were solubilized in $\mathrm{Me}_{2} \mathrm{SO}-d_{6}$ at 15 and $40 \mathrm{mg} \cdot \mathrm{mL}^{-1}$ for ${ }^{1} \mathrm{H}$ and ${ }^{13} \mathrm{C}$, respectively. Chemical shifts are expressed in ppm relative to $\mathrm{Me}_{2} \mathrm{SO}-d_{6}$ resonances at 2.50 and $39.5 \mathrm{ppm}$ for ${ }^{1} \mathrm{H}$ and ${ }^{13} \mathrm{C}$, respectively.

\subsection{Adhesion Assay}

A microplate method, previously described by Becker et al. [31] and Ganner et al. [32], and adapted by Rodrigues, Duarte, and Noseda [15], was used to determine the ability of microalgal molecules to specifically adhere to Salmonella Typhimurium.

\subsubsection{Bacteria Strain and Culture Conditions}

Salmonella enterica sv. Typhimurium ATCC 14028 strain was maintained at $4{ }^{\circ} \mathrm{C}$ in Brain Heart Infusion Agar (HiMedia Laboratories Ltd., Mumbai, MH, India) under aerobic conditions and subcultured at 15-day intervals. Bacteria were transferred to Tryptic Soy Broth (TSB, HiMedia Laboratories Ltd.), incubated overnight at $37^{\circ} \mathrm{C}$ under aerobic conditions, and subcultured to a fresh medium for $2 \mathrm{~h}$ at $37^{\circ} \mathrm{C}$. The optical density (OD) of the bacterial suspension was adjusted to 0.01 (at $690 \mathrm{~nm}$ ) with PBS (phosphate-buffered saline: $10 \mathrm{mmol} \cdot \mathrm{L}^{-1}$ sodium phosphate, $0.15 \mathrm{~mol} \cdot \mathrm{L}^{-1}$ sodium chloride, $\mathrm{pH}$ 7.0) for the experiments.

\subsubsection{Calibration Curve}

Serial dilutions of freshly prepared cultures were plated in triplicate on Tryptic Soy Agar (HiMedia Laboratories Ltd.,) and incubated for $24 \mathrm{~h}$ prior to CFU enumeration. Simultaneously, eight replicates of each bacterial suspension were incubated, $200 \mu \mathrm{L}$ per well, in a microplate reader (SpectraMax 340, Molecular Devices LLC, San Jose, CA, USA) for $18 \mathrm{~h}$ at $37^{\circ} \mathrm{C}$. The OD at $690 \mathrm{~nm}$ was determined at intervals of $15 \mathrm{~min}$, with automatic shaking taking place for $3 \mathrm{~s}$ prior to every reading. A calibration curve (linear regression) was produced by plotting the time in hours necessary for bacterial solutions to reach an $\mathrm{OD}$ of $0.1\left(\mathrm{t}_{\mathrm{OD}}\right)$ versus the number of counted bacteria on an agar plate $\left(\mathrm{CFU} \cdot \mathrm{mL}^{-1}\right)$ to calculate the number of bacteria originally connected to the studied fractions.

\subsubsection{Assay}

Microalgal extracts were suspended in PBS $(1 \% \mathrm{~m} / \mathrm{v})$ and subsequently homogenized in an ultrasonic bath (three times for $30 \mathrm{~s}$ each) (coating solutions). For coatings, $300 \mu \mathrm{L} /$ well of the coating solutions were pipetted into flat-bottom wells of a high-binding microtitration plate (Costar 3590, Corning Inc., Corning, NY, USA) and incubated overnight at $4{ }^{\circ} \mathrm{C}$. The plate was washed three times with $300 \mu \mathrm{L}$ of PBS, and subsequently, wells were blocked with $300 \mu \mathrm{L}$ of $1 \%(\mathrm{~m} / v)$ bovine serum albumin (BSA) in PBS at $4{ }^{\circ} \mathrm{C}$ for $1 \mathrm{~h}$. Thereafter, the plate was washed three times with PBS and bacterial suspension OD 0.01 was added $\left(300 \mu \mathrm{L} /\right.$ well). Bacteria were allowed to adhere for $1 \mathrm{~h}$ at $37^{\circ} \mathrm{C}$, and then, wells were washed six times with PBS. Finally, $200 \mu \mathrm{L}$ of TSB and one drop of paraffin-oil were added, and the bacterial growth was monitored using the OD $(690 \mathrm{~nm})$ at $37^{\circ} \mathrm{C}$, for $16 \mathrm{~h}$ at intervals of $15 \mathrm{~min}$, with automatic shaking taking place for $3 \mathrm{~s}$ prior to every reading. All readings were performed for three independent assays and in triplicate per assay. 
Blank samples, negative controls, growth controls, positive controls, and media controls were also assessed on each plate. Blank samples consisted of coating solutions and BSA but without bacteria. A negative control consisted of BSA and bacteria but without coating solutions. A growth control consisted of non-coated wells containing a suspension of bacteria (OD 0.01) in TSB. A commercially available yeast cell wall-derived product was used as the positive control. Blank and media controls showed no growth during the experimental time $(16 \mathrm{~h})$ and the negative control showed growth after $7 \mathrm{~h}$.

\subsubsection{Data Processing and Statistics}

Data generated using the photometer software (Soft-Max Pro version 2.2.1; Molecular Devices LLC) were converted into text files and analyzed using R Software (version 2.15.1; The R Foundation for Statistical Computing, Vienna, Austria). All OD data were processed using non-linear regression analysis employing a bacterial kinetic model [31]. The $\mathrm{t}_{\mathrm{OD}}(\mathrm{h})$ were transformed into $\log \mathrm{CFU} \cdot \mathrm{mL}^{-1}$ by means of fitted linear regressions: $y=-0.7693 x+9.0485\left(R^{2}=995\right)$, where " $y$ " corresponds to $t_{O D}$ and " $x$ " to the log of CFU/well (see the calibration curve) [32]. The data were statistically evaluated by applying an analysis of variance (ANOVA) and differences between the mean values were tested using Tukey's test. Data with a $p$-value lower than 0.05 was considered statistically significant.

\section{Results}

\subsection{Extraction and Characterization of Polysaccharides from P. gyrans and P. lutheri}

Dried biomasses of $P$. gyrans and P. lutheri were extracted under sequential aqueous extraction followed by alkaline extraction. Crude aqueous and alkaline extracts were treated with EtOH, and ethanolic precipitates were submitted to freeze-thawing and dialysis, producing the fractions GW-p (0.9\%), GW-s (3.8\%), GA-p (1.2\%), and GA-s (0.4\%) from P. gyrans, and LW-p (0.6\%), LW-s (4.7\%), LA-p (1.0\%), and LA-s (0.9\%) from P. lutheri (Figure 1) (G and L fractions correspond to P. gyrans and P. lutheri, respectively; $\mathrm{W}$ and $\mathrm{A}$ correspond to aqueous and alkaline extracts, respectively; and $\mathrm{p}$ and s correspond to precipitated and supernatant extracts, respectively). Table 1 shows the chemical analyses and monosaccharide compositions of these fractions. The aqueous fractions from $P$. gyrans (GW-p, GW-s) and P. lutheri (LW-p, LW-s) showed a high content of carbohydrates, with contents varying from $55.6 \%$ in $\mathrm{LW}-\mathrm{p}$ to $83.5 \%$ in GW-p. These fractions were mainly constituted by glucose (85.4-100 mol\%), indicating the presence of glucans. The alkaline fractions (GA-p, GA-s, LA-p, LA-s) were predominantly composed of proteins, with contents varying from $30.0 \%$ in GA-p to $49.1 \%$ in LA-p. The carbohydrate contents varied from $11.6 \%$ in GA-p to $17.5 \%$ in LA-s, and the monosaccharide analysis indicated three main sugars: glucose, galactose, and mannose. Other monosaccharides were present in lower amounts in these fractions.

Table 1. Chemical analyses and monosaccharide composition of fractions from P. gyrans and P. lutheri.

\begin{tabular}{|c|c|c|c|c|c|c|c|c|c|}
\hline \multirow{2}{*}{ Fraction } & \multirow{2}{*}{$\begin{array}{c}\text { Carbohydrate } \\
(\%)\end{array}$} & \multirow{2}{*}{$\begin{array}{c}\text { Protein } \\
(\%)\end{array}$} & \multicolumn{7}{|c|}{ Monosaccharides (mol\%) } \\
\hline & & & Rha & Fuc & Ara & Xyl & Man & Gal & Glc \\
\hline \multicolumn{10}{|c|}{ P. gyrans } \\
\hline GW-p & 83.5 & 10.7 & $\operatorname{tr}$ & $\operatorname{tr}$ & $\operatorname{tr}$ & $\operatorname{tr}$ & $\operatorname{tr}$ & $\operatorname{tr}$ & 100 \\
\hline GW-s & 68.6 & 18.1 & 1.4 & 1.2 & 1.1 & $\operatorname{tr}$ & 2.8 & 2.7 & 90.8 \\
\hline GA-p & 11.6 & 30.0 & 5.2 & 6.5 & 3.7 & 10.6 & 21.6 & 16.0 & 36.4 \\
\hline GA-s & 15.3 & 38.4 & 4.1 & 6.6 & 8.9 & 11.5 & 12.2 & 24.2 & 32.5 \\
\hline \multicolumn{10}{|c|}{ P. lutheri } \\
\hline$L W-p$ & 55.6 & 14.5 & 2.1 & 2.5 & $\operatorname{tr}$ & $\operatorname{tr}$ & 1.5 & 2.0 & 91.8 \\
\hline LW-s & 59.9 & 17.9 & 1.4 & 3.7 & 1.8 & $\operatorname{tr}$ & 3.4 & 4.3 & 85.4 \\
\hline LA-p & 15.2 & 49.1 & 8.3 & 7.8 & 3.0 & 5.1 & 14.2 & 17.6 & 44.0 \\
\hline LA-s & 17.5 & 34.7 & 5.5 & 7.7 & 8.2 & 8.1 & 15.4 & 24.9 & 30.2 \\
\hline
\end{tabular}

tr: Percentages lower than $1 \mathrm{~mol} \%$. 
Thermogravimetric analyses were performed to complement the chemical composition of the microalgal fractions. Thermogravimetric (TG) curves, derivative thermogravimetric (DTG) curves, and characteristics of the microalgal extracts in the TGA process are shown in Table 2 and Figure 2. Although the fractions have different chemical compositions, three stages could be identified for all microalgal fractions that were similar to the previously published works [33,34].

Table 2. Characteristic total volatile matter content (\%) of the different stages for microalgal extracts at a heating rate of $10^{\circ} \mathrm{C} \cdot \mathrm{min}^{-1}$.

\begin{tabular}{|c|c|c|c|c|}
\hline \multirow{2}{*}{ Fraction } & \multicolumn{3}{|c|}{ Total Volatile Matter Content $(\%)^{a}$} & \multirow{2}{*}{ Ash and Fixed Carbon (\%) } \\
\hline & Stage 1 & Stage 2 & Stage 3 & \\
\hline \multicolumn{5}{|c|}{ P. gyrans } \\
\hline GW-p & 9.2 & 78.7 & 5.5 & 6.5 \\
\hline GW-s & 7.0 & 66.1 & 16.8 & 10.1 \\
\hline GA-p & 8.8 & 63.6 & 17.4 & 10.1 \\
\hline GA-s & 8.6 & 58.0 & 22.5 & 10.8 \\
\hline \multicolumn{5}{|c|}{ P. lutheri } \\
\hline$L W-p$ & 4.6 & 72.8 & 12.3 & 10.3 \\
\hline LW-s & 10.1 & 55.6 & 17.8 & 16.5 \\
\hline LA-p & 10.0 & 64.7 & 18.1 & 7.1 \\
\hline LA-s & 8.3 & 56.1 & 15.4 & 20.1 \\
\hline
\end{tabular}
a Stage 1: Range from 20 to $150{ }^{\circ} \mathrm{C}$; Stage 2: Range from 150 to $500{ }^{\circ} \mathrm{C}$; Stage 3: Range from 500 to $800{ }^{\circ} \mathrm{C} .{ }^{\mathrm{b}}$
Non-degradable residue at $800{ }^{\circ} \mathrm{C}$.

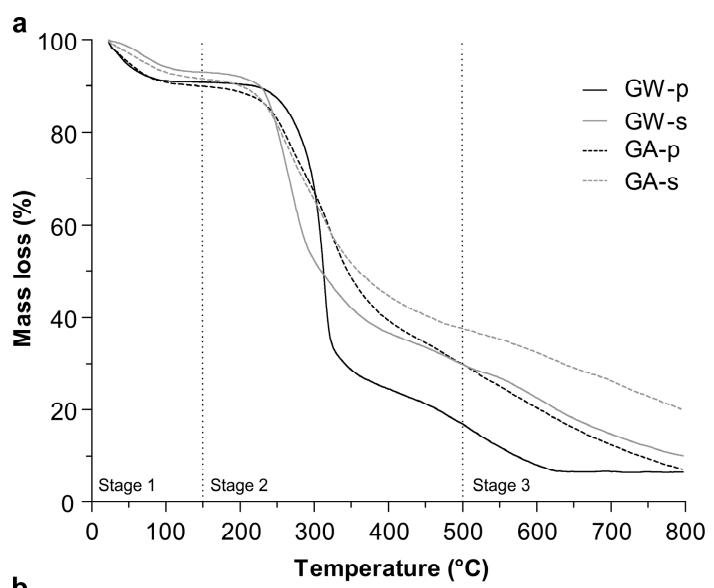

b

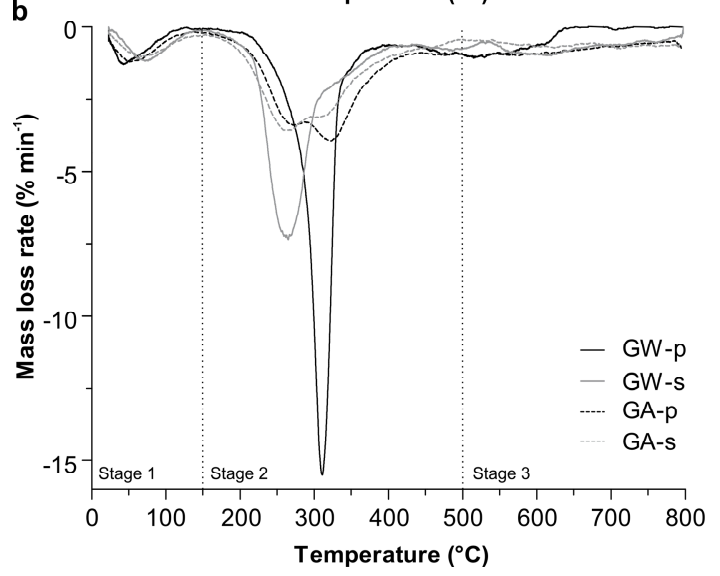

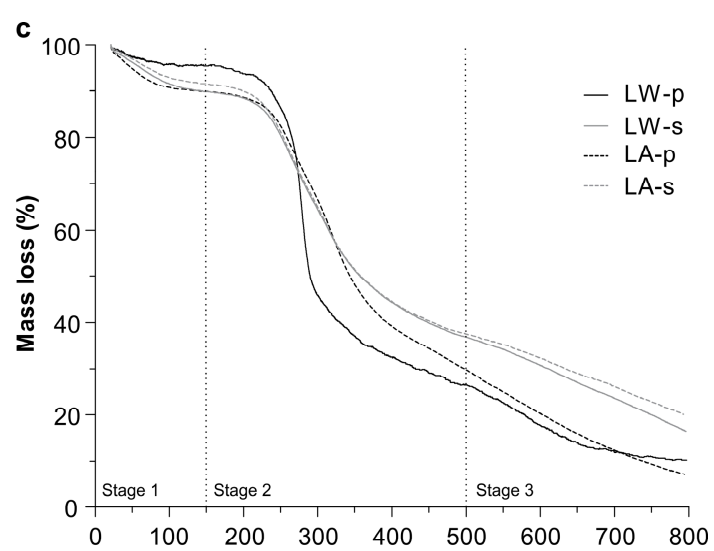

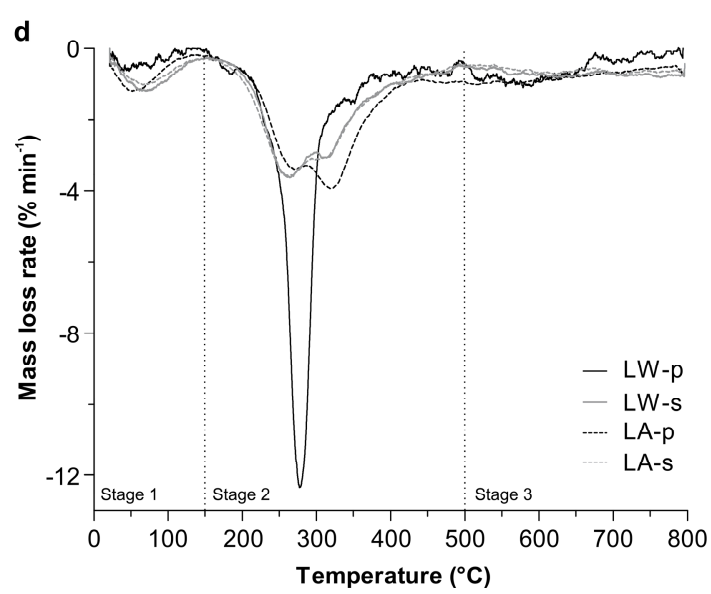

Figure 2. Thermogravimetric $(\mathbf{a}, \mathbf{c})$ and derivative thermogravimetric curves $(\mathbf{b}, \mathbf{d})$ of aqueous and alkaline fractions from P. gyrans (GW-p, GW-s, GA-p, GA-s) and P. lutheri (LW-p, LW-s, LA-p, LA-s) at a heating rate of $10^{\circ} \mathrm{C} \cdot \mathrm{min}^{-1}$ under a nitrogen atmosphere. 
In the first stage of the decomposition process, ranging from $20-150{ }^{\circ} \mathrm{C}$, a slight mass loss in the TG curves was observed (4.6\%-10.1\%) due to water loss (free and loosely bound water) and some light volatile compounds. By comparing the first stage in the DTG curves (Figure 2b,d), the results showed subtle differences in the peak temperatures between 41.8 and $70.6{ }^{\circ} \mathrm{C}$. These differences might have been due to the location and intermolecular forces between water molecules and the carbonaceous matrix that influenced the water elimination, and consequently, the peak temperatures [35]. The second stage of decomposition, between 150 and $500^{\circ} \mathrm{C}$, represented the main devolatilization reaction, where most of the sample mass was released as volatile matter. This stage involved the decomposition of microalgae organic substances, including proteins and carbohydrates, present in all the studied fractions (Table 1). The percentages of volatile matter (Table 2) were between $55.6 \%$ and $66.1 \%$ of the initial mass, except for GW-p and LW-p, which showed higher values (78.7\% and 72.8\%, respectively). The GW-p and LW-p DTG curves showed one intense sharp peak, indicating a high mass-loss rate; however, for $\mathrm{GW}-\mathrm{p}$, the inflection point was observed at $310^{\circ} \mathrm{C}$, while for $\mathrm{LW}$-p, the inflection point was at $277^{\circ} \mathrm{C}$. One peak was also distinguished in this stage for GW-s at $264^{\circ} \mathrm{C}$. These differences in the thermal profiles may have been due to different chemical compositions, or differences in the linkage pattern of glucans present in these fractions [36,37]. Stage 2 in the DTG curves (Figure 2b,d) of alkaline fractions (GA-p, GA-s, LA-p, LA-s) was complex as multiple overlapping peaks and wide shoulders were visible, in agreement with the chemical composition complexity observed for these fractions (Table 1). In the third stage, at temperatures higher than $500{ }^{\circ} \mathrm{C}$, the carbonaceous materials retained in the solid residues were decomposed at a slow rate, resulting in the formation of a non-degradable residue. For nearly all the fractions, the percentage of non-degradable residue at $800{ }^{\circ} \mathrm{C}$ (Table 2) accounted for $6.5 \%-10.8 \%$ of the initial mass, with a higher value for LW-s and LA-s $(16.5 \%$ and $20.1 \%$, respectively).

To elucidate the linkage pattern of the polysaccharides present in the aqueous fractions, GW-p and GW-s were submitted to methylation analysis, and the results are shown in Table 3. The methylation analysis of fraction GW-p revealed the major presence of the derivative 2,4,6-tri-O-methyl glucitol $(90.0 \%)$, suggesting the presence of a main linear backbone constituted by 3-O-substituted glucopyranosyl units. In addition, the methylation analysis showed minor proportions of non-reducing terminal units, as well as 6- and 3,6-di-O-substituted glucopyranosyl units. The relative amount of nonbranched and disubstituted Glc $p$ residues indicated one branching point for every $\approx 20$ Glc $p$ residues. In contrast, GW-s showed a highly branched structure, with non-reducing terminal, 3-, 6-, and 3,6-di-O-substituted glucopyranosyl units, indicating the presence of a $(1 \rightarrow 3),(1 \rightarrow 6)$-linked glucan, with one branching point every approximately four Glc $p$ residues.

Table 3. Methylation analysis of GW-p and GW-s.

\begin{tabular}{|c|c|c|c|}
\hline \multirow{2}{*}{ Sugar Derivative ${ }^{a}$} & \multirow{2}{*}{ Deduced Linkages ${ }^{b}$} & \multicolumn{2}{|c|}{ Molar Ratio $^{c}$} \\
\hline & & GW-p & GW-s \\
\hline $2,3,4,6-\mathrm{Me}_{4}-\mathrm{GlC}^{\mathrm{d}}$ & Glc $p-(1 \rightarrow$ & 7.3 & 38.0 \\
\hline $2,4,6-\mathrm{Me}_{3}-\mathrm{Glc}$ & $\rightarrow 3)$-Glcp-(1 $\rightarrow$ & 90.0 & 26.7 \\
\hline $2,3,4-\mathrm{Me}_{3}-\mathrm{Glc}$ & $\rightarrow 6)$-Glcp-(1 $\rightarrow$ & 2.5 & 11.2 \\
\hline 2,4-Me $2-G l c$ & $\rightarrow 3,6)$-Glcp-( $(1 \rightarrow$ & 5.3 & 24.1 \\
\hline
\end{tabular}

\footnotetext{
a Monosaccharide bearing a methyl group in the indicated position. ${ }^{\mathrm{b}}$ Based on derived O-methyl alditol acetates. c Expressed in $\mathrm{mol} \%$ of the total O-methylalditol acetates. d 2,3,4,6-Me $\mathrm{Me}_{4}$-Glc analyzed as 1,5-di-O-acetyl-2,3,4,6-tetra-O-methyl glucitol.
}

Fractions were also examined using NMR spectroscopy. ${ }^{1} \mathrm{H}$ and ${ }^{13} \mathrm{C}$ NMR assignments were determined using spectral information from 1D and 2D NMR experiments and previously reported data. The ${ }^{13} \mathrm{C}$ NMR spectra of GW-p (Figure 3a) and LW-p (data not shown) demonstrated six major signals at $102.4,72.3,85.6,67.9,75.8$, and $60.4 \mathrm{ppm}$, which were assigned to the six-membered ring of $\beta$-D-Glc $p$ units (residue $G_{L}$ ), the major component of these fractions. The anomeric signal at $4.53 \mathrm{ppm}$ $\left(J_{\mathrm{H} 1, \mathrm{H} 2} 7.7 \mathrm{~Hz}\right)$ in the ${ }^{1} \mathrm{H}$ NMR spectrum confirmed the $\beta$-anomericity of these units. The cross-peak in 
the HSQC spectrum (Figure 4a) at 3.49/85.6 ppm indicated the 3-O-substitution of $\beta$-D-Glcp residues. The non-substitution at O-6 was confirmed by the ${ }^{13} \mathrm{C}$-DEPT inverted resonance at $60.4 \mathrm{ppm}$. All the ${ }^{1} \mathrm{H}$ and ${ }^{13} \mathrm{C}$ NMR assignments of GW-p are shown in Table 4 . The spectroscopic analyses indicated the occurrence of a $(1 \rightarrow 3)$-linked $\beta$-glucan in the GW-p fraction.

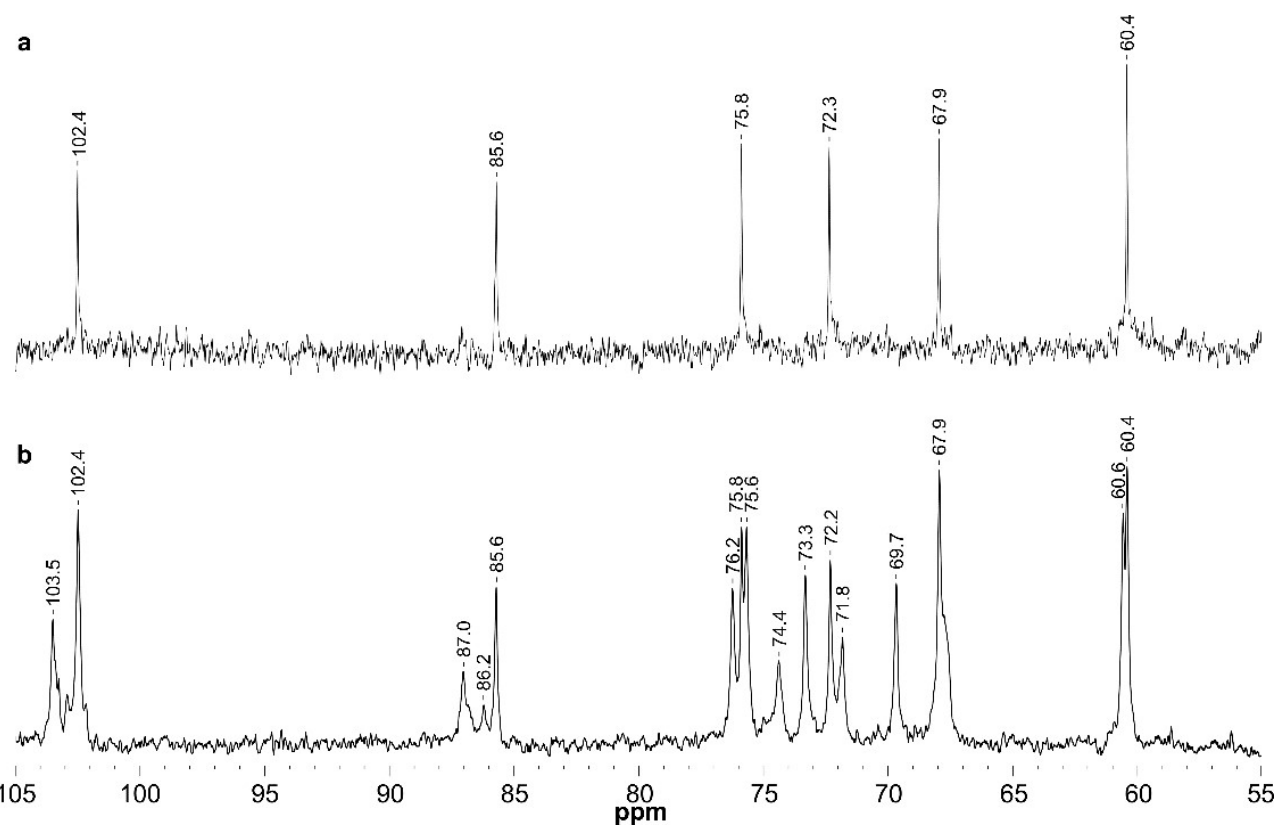

Figure $3 .{ }^{13} \mathrm{C}$ NMR spectra $\left(100.63 \mathrm{MHz}, \mathrm{Me}_{2} \mathrm{SO}-\mathrm{d}_{6}, 70^{\circ} \mathrm{C}\right)$ of GW-p (a) and GW-s (b).
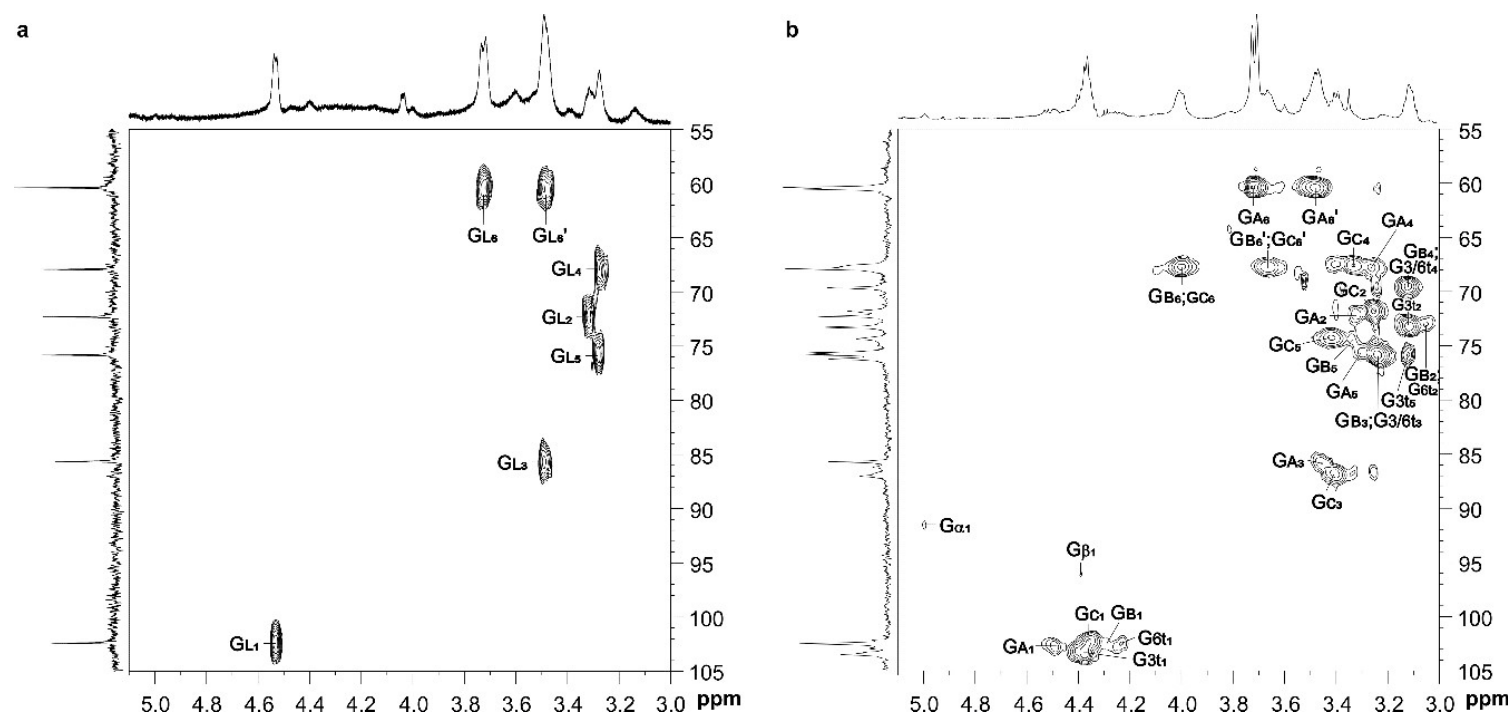

Figure 4. HSQC spectra $\left(400 \mathrm{MHz}, \mathrm{Me}_{2} \mathrm{SO}-d_{6}, 70{ }^{\circ} \mathrm{C}\right)$ of $\mathrm{GW}-\mathrm{p}(\mathbf{a})$ and $\mathrm{GW}-\mathrm{s}(\mathbf{b}) . \mathrm{G}_{\mathrm{L}}$ and $G_{A}$ correspond to $[\rightarrow 3)-\beta-\mathrm{D}-\mathrm{Glc} p-(1 \rightarrow]$, and $\mathrm{G}_{\mathrm{B}}, \mathrm{G}_{\mathrm{C}}, \mathrm{G}_{3 \mathrm{t}}, \mathrm{G}_{6 \mathrm{t}}, \mathrm{G}_{\alpha}$, and $\mathrm{G}_{\beta}$ correspond to $[\rightarrow 6)-\beta$-D-Glcp- $(1 \rightarrow],[\rightarrow 3,6)-\beta-\mathrm{D}-G l c p-(1 \rightarrow],[\beta-\mathrm{D}-G l c p-(1 \rightarrow 3],[\beta-\mathrm{D}-\mathrm{Gl} c p-(1 \rightarrow 6],[\rightarrow 3)-\alpha-\mathrm{D}-\mathrm{Gl} c p]$, and $[\rightarrow 3)-\beta-\mathrm{D}-\mathrm{Gl} c p]$ residues, respectively. 
Table 4. ${ }^{1} \mathrm{H}$ and ${ }^{13} \mathrm{C}$ NMR chemical shifts of GW-p and GW-s.

\begin{tabular}{|c|c|c|c|c|c|c|c|c|}
\hline \multirow{2}{*}{ Fraction } & \multirow{2}{*}{ Glycosyl Residues } & & \multicolumn{6}{|c|}{ Chemical Shifts $^{a}$} \\
\hline & & & $\mathrm{H}-1 / \mathrm{C}-1$ & $\mathrm{H}-2 / \mathrm{C}-2$ & $\mathrm{H}-3 / \mathrm{C}-3$ & $\mathrm{H}-4 / \mathrm{C}-4$ & H-5/C-5 & H-6;H-6'/C-6 \\
\hline GW-p & $\rightarrow 3)-\beta-\mathrm{D}-\mathrm{Glc} p-(1 \rightarrow$ & $\mathrm{G}_{\mathrm{L}}$ & $4.53 / 102.4$ & $3.32 / 72.3$ & $3.49 / 85.6$ & $3.28 / 67.9$ & $3.28 / 75.8$ & $3.72 ; 3.48 / 60.4$ \\
\hline \multirow{7}{*}{ GW-s } & $\rightarrow 3)-\alpha-\mathrm{D}-\mathrm{Gl} c p$ & $\mathrm{G}_{\alpha}$ & $5.00 / 91.5$ & nd & nd & nd & nd & nd \\
\hline & $\rightarrow 3)-\beta-\mathrm{D}-\mathrm{Gl} c p$ & $\mathrm{G}_{\beta}$ & $4.39 / 96.1$ & nd & nd & nd & nd & nd \\
\hline & $\beta$-D-Glc $p-(1 \rightarrow 3$ & $\mathrm{G}_{3 \mathrm{t}}$ & $4.38 / 103.5$ & $3.11 / 73.5$ & $3.24 / 75.6$ & $3.12 / 69.7$ & $3.12 / 75.8$ & $3.72 ; 3.47 / 60.7$ \\
\hline & $\beta$-D-Glc $p-(1 \rightarrow 6$ & $\mathrm{G}_{6 \mathrm{t}}$ & $4.23 / 102.5$ & $3.05 / 73.3$ & $3.23 / 75.6$ & $3.13 / 69.7$ & $3.19 /$ nd & $3.71 ; 3.49 / 60.7$ \\
\hline & $\rightarrow 3)-\beta-\mathrm{D}-\mathrm{Gl} c p-(1 \rightarrow$ & $\mathrm{G}_{\mathrm{A}}$ & $4.49 / 102.4$ & $3.32 / 72.2$ & $3.46 / 85.6$ & $3.26 / 67.9$ & $3.29 / 75.8$ & $3.72 ; 3.48 / 60.4$ \\
\hline & $\rightarrow 6)-\beta$-D-Glcp-(1 $\rightarrow$ & $\mathrm{G}_{\mathrm{B}}$ & $4.28 / 102.6$ & $3.05 / 73.3$ & $3.23 / 75.8$ & $3.15 / 69.7$ & $3.34 / 74.4$ & $4.00 ; 3.61 / 67.9$ \\
\hline & $\rightarrow 3,6)-\beta$-D-Glcp-( $1 \rightarrow$ & $\mathrm{G}_{\mathrm{C}}$ & $4.36 / 102.4$ & $3.25 / 72.0$ & $3.40 / 87.0$ & $3.33 / 67.8$ & $3.42 / 74.4$ & $4.00 ; 3.66 / 67.9$ \\
\hline
\end{tabular}

nd: Not determined. ${ }^{a}$ In ppm relative to $\mathrm{Me}_{2} \mathrm{SO}-d_{6}$ resonances.

The ${ }^{13} \mathrm{C}$ NMR analyses of fractions GW-s (Figure $3 b$ ) and LW-s (data not shown) showed signals of $(1 \rightarrow 3)$-linked $\beta$-Glcp residues at 102.4, 72.2, 85.6, 67.9, 75.8, and $60.4 \mathrm{ppm}$, which were attributed to C-1-C-6, respectively. Additionally, the HSQC spectrum (Figure 4b) contained anomeric correlations (H-1/C-1) at 4.38/103.5 and 4.23/102.5 ppm, corresponding to non-reducing end units (residues $\mathrm{G}_{3 \mathrm{t}}$ and $\mathrm{G}_{6 \mathrm{t}}$, respectively), and others at 4.28/102.6 and 4.36/102.4 ppm, corresponding to 6$\left(\mathrm{G}_{\mathrm{B}}\right)$ and 3,6-di-O-substituted Glcp residues $\left(\mathrm{G}_{\mathrm{C}}\right)$, respectively. Furthermore, the HSQC cross-peaks at 5.00/91.5 and 4.39/96.1 ppm were attributed to H-1/C-1 of $\alpha-\left(\mathrm{G}_{\alpha}\right)$ and $\beta$-reducing end Glcp residues $\left(G_{\beta}\right)$, respectively. The correlation at 3.40/87.0 ppm arose from a substitution at O-3 in $(1 \rightarrow 3,6)$-linked $\beta$-D-Glcp units, while those at 3.23/75.6, 3.24/75.6, and 3.23/75.8 ppm were from free O-3 of non-reducing ends and $(1 \rightarrow 6)$-linked $\beta$-D-Glc $p$ units. The ${ }^{13} \mathrm{C}$ DEPT-135 inverted resonance at $67.9 \mathrm{ppm}$ corresponded to substituted $\mathrm{CH}_{2}-6$ of $\beta$-D-Glcp units, while the inverted signals at 60.7 and $60.4 \mathrm{ppm}$, could be attributed to unsubstituted $\mathrm{CH}_{2}-6$ of $\beta$-D-Glc $p$ units. All the ${ }^{1} \mathrm{H}$ and ${ }^{13} \mathrm{C}$ NMR assignments, based on HSQC (Figure 4), COSY (Figure S1), and TOCSY (Figure S2) spectra, presented in Table 4 are in agreement with previously reported resonances [38-41]. In accordance with the methylation analysis, the NMR data suggest the presence of a highly branched $\beta$-D-glucan constituted by a $(1 \rightarrow 3)$-linked main chain substituted at O-6 by single units of D-Glc $p$ or $(1 \rightarrow 6)$-linked $\beta$-D-Glc $p$ branches.

The HSQC NMR spectrum (Figure 5a) of the alkaline fraction LA-p, showed an anomeric correlation at $4.59 / 98.4 \mathrm{ppm}\left(\mathrm{JH}_{\mathrm{H}, \mathrm{H} 2} 3.7 \mathrm{~Hz}\right)$, which is consistent with an $\alpha$-glycosidic configuration. Correlations at an unusual high field region $(2.89 ; 2.64 / 54.9 \mathrm{ppm})$ indicated the presence of a $-\mathrm{CH}_{2}-\mathrm{SO}_{3}{ }^{-}$group of 6-sulfoquinovose units. The ${ }^{13} \mathrm{C}$-DEPT inverted signal at $54.9 \mathrm{ppm}\left(\mathrm{CH}_{2}\right)$ confirmed the S-substituted C-6 (Figure 5c'). The H-2/C-2-H-5/C-5 correlations at 3.22/71.3, 3.4/72.6, 3.02/74.3, and 3.82/68.1 ppm, respectively, also confirmed the presence of a quinovosyl structure (residue SQ). Furthermore, the HSQC spectrum (Figure 5a) contained correlations at 3.87;3.46/64.7, 5.14/69.7, and 4.35;4.15/62.0, which were attributed, respectively, to $\mathrm{H}-1 ; \mathrm{H}-\mathrm{1}^{\prime} / \mathrm{C}-1, \mathrm{H}-2 / \mathrm{C}-2$, and $\mathrm{H}-3 ; \mathrm{H}-3^{\prime} / \mathrm{C}-3$ of linked glycerol (Gly), indicating the presence of the glycoside sulfoquinovosylglycerol (SQG). Moreover, the anomeric region contained two low-intensity correlations at 4.14/103.5 ppm $\left(J_{\mathrm{H} 1, \mathrm{H} 2} 7.1 \mathrm{~Hz}\right)$ and $4.72 / 99.0 \mathrm{ppm}\left(\mathrm{J}_{\mathrm{H} 1, \mathrm{H} 2} 3.3 \mathrm{~Hz}\right)$, which were attributed to $\beta$-Galp and $\alpha$-Galp units, respectively, suggesting the presence of a second glycoside in this fraction, namely digalactosylglycerol (DGG) [42-44]. The $\mathrm{CH}_{3}$ correlations at $0.86 / 13.3 \mathrm{ppm}$, $\mathrm{CH}_{2}$ at 1.20/21.1 to 2.3/36.6 ppm with a predominant one at 1.25/28.5 ppm (inverted resonances in the ${ }^{13} \mathrm{C}$-DEPT spectrum, Figure $\left.5 \mathrm{c}^{\prime}\right)$, and carboxylic signals at $171-175 \mathrm{ppm}$ in the ${ }^{13} \mathrm{C}$ NMR spectra (Figure 5c), as well as double-bond correlations from 5.05/119.8 to 5.50/137.3 ppm, indicated the presence of unsaturated free fatty acid chains [45]. 


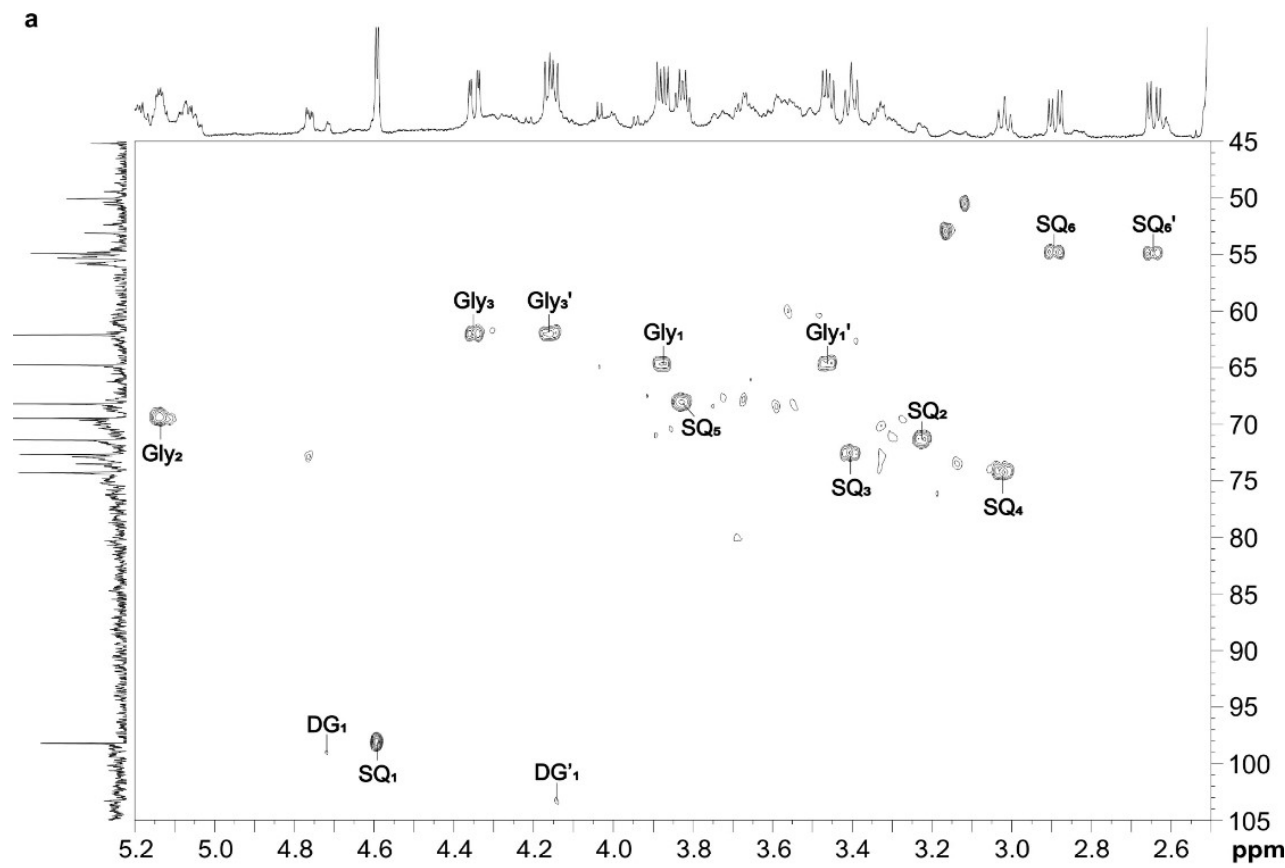

b
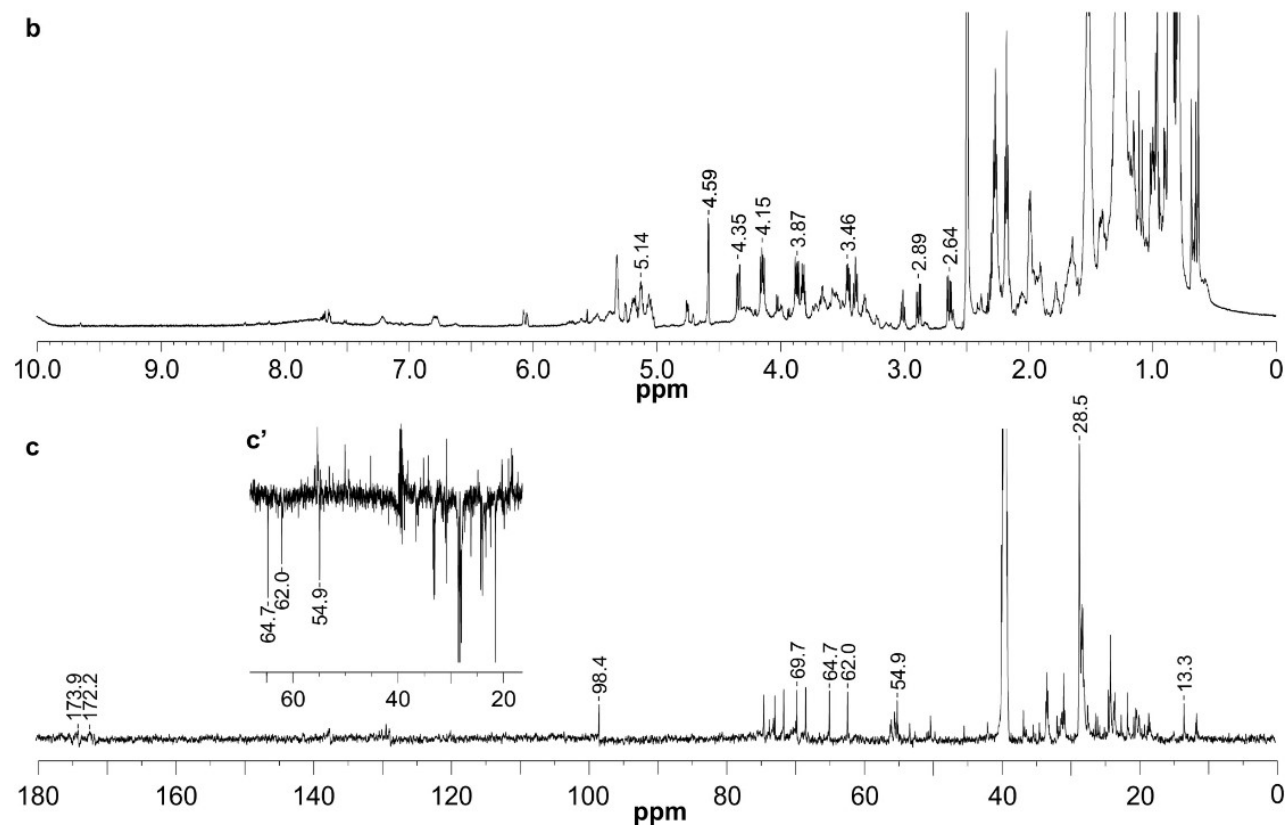

Figure 5. NMR analyses of the LA-p fraction. ${ }^{1} \mathrm{H}-{ }^{13} \mathrm{C} \mathrm{HSQC}(\mathbf{a}),{ }^{1} \mathrm{H}$ NMR (b), ${ }^{13} \mathrm{C}$ NMR (c), and partial ${ }^{13} \mathrm{C}$-DEPT-135 spectra $\left(\mathbf{c}^{\prime}\right)\left(\mathrm{Me}_{2} \mathrm{SO}-d_{6}, 70{ }^{\circ} \mathrm{C}\right)$. DG, SQ, and Gly correspond to the glycosyl moiety of digalactosylglycerol and sulfoquinovosylglycerol, and the linked glycerol units, respectively.

Additional to glycosides and free fatty acid signals, the ${ }^{1} \mathrm{H}$ and ${ }^{13} \mathrm{C}$ NMR spectra of LA-p (Figure 5) showed protein signals in accordance with the high protein content $(49.1 \%)$ observed in the chemical analyses. Overlapping was expected for some of the protein and free fatty acid resonances. The ${ }^{1} \mathrm{H}$ NMR spectrum (Figure 5b) showed signals in the region of the backbone amide protons (10.0-7.0 ppm), aromatic and side-chain amide protons (8.0-6.0 ppm), $\alpha$-proton (5.5-3.5 ppm), methine, methylene (3.5-1.0 ppm), and methyl protons (2.0-0 ppm) of the aliphatic side chains [46]. The ${ }^{13} \mathrm{C}$ NMR spectrum (Figure 5c) showed signals corresponding to the carbonyl carbon of the main chain and carboxylic groups of the acidic amino acids side chain (180-165 ppm), aromatic amino acids (140-115 ppm), $\alpha$ and $\beta$ carbons (65-45 ppm and 45-25 ppm, respectively), and methylene and methyl groups of the aliphatic side chains (25-10 ppm) [47]. 
The ${ }^{1} \mathrm{H}$ NMR spectra of the other alkaline fractions, LA-s, GA-s, and GA-p (data not shown), presented the same characteristic protein resonances that were described for the LA-p fraction. Free fatty acid NMR signals were also observed in the GA-p fraction. The LA-s and GA-s fractions showed a low-intensity anomeric resonance at $4.53 \mathrm{ppm}\left(\mathrm{J}_{\mathrm{H} 1, \mathrm{H} 2} 7.6 \mathrm{~Hz}\right)$, which was attributed to $\mathrm{H}-1$ of $(1 \rightarrow 3)$-linked $\beta$-glucan; however, no other signal in the carbohydrate region could be detected.

\subsection{Adhesion Test}

The ability of microalgal fractions to adhere to Salmonella Typhimurium was determined using an in vitro assay and the results are shown in Figure 6. The quantitative adhesion numbers (CFU) between bacteria and microalgal fractions were determined using linear regression, where a higher number of bound bacteria results in an earlier entry into the exponential phase and indicates a higher adhesion capacity. The results indicated three different levels of adhesion, which involved binding between $1.28 \times 10^{3}$ and $1.52 \times 10^{4} \mathrm{CFU}$. The group including alkaline fractions GA-s and LA-s showed the lower detection times of $\approx 6.5 \mathrm{~h}$ and exhibited the highest adhesion capacity, adhering between $98 \%$ and $140 \%$ more bacteria than the positive control (yeast cell wall-derived product). The precipitated fractions from alkaline (GA-p, LA-p) and aqueous extracts (GW-p, LW-p) exhibited low adhesion capacity, with detection times of $6.90-7.06 \mathrm{~h}$, adhering $12 \%-34 \%$ fewer bacteria than the positive control. Fractions from the aqueous extracts, LW-s and GW-s, had no adhesion capacity, showed longer detection times $(>7.4 \mathrm{~h}$ ), and yielded similar results to those of the negative control (bovine serum albumin).

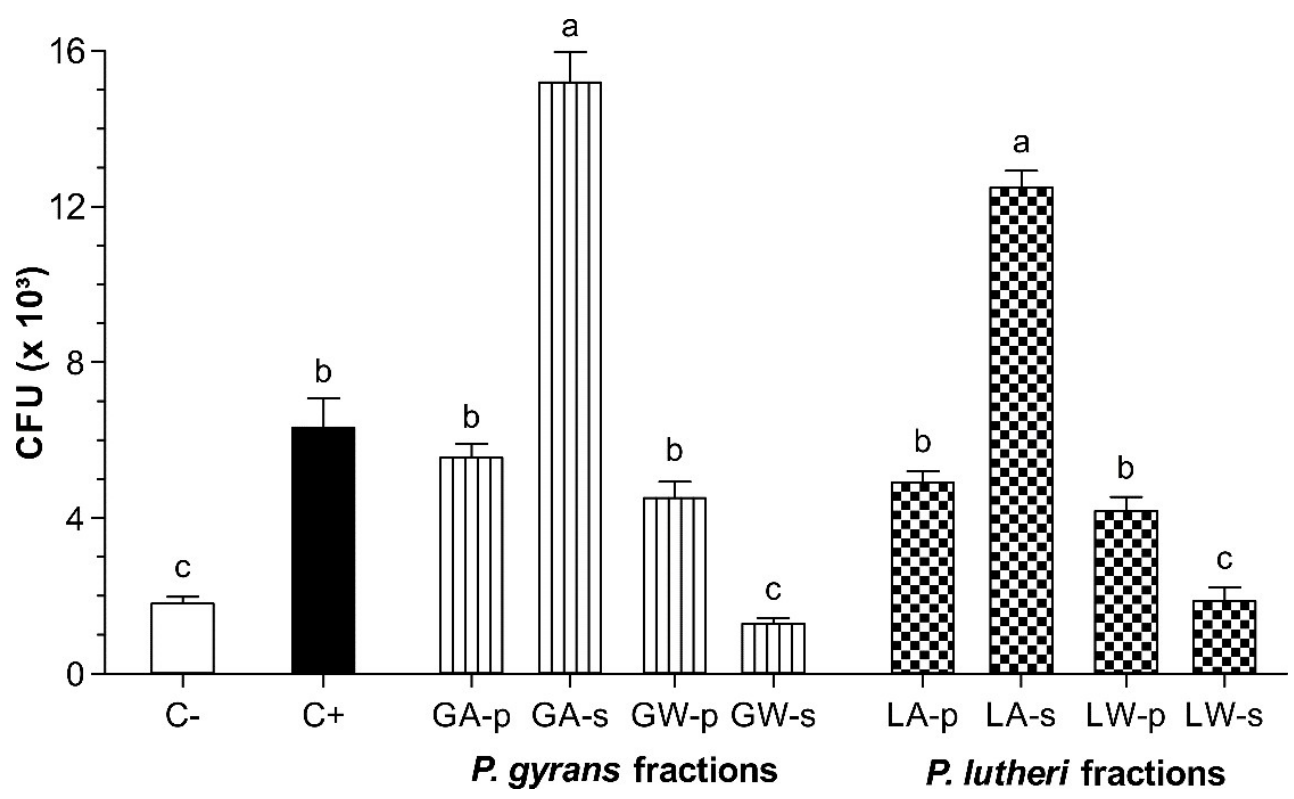

Figure 6. Number of Salmonella Typhimurium attached to wells coated with microalgal extracts in the adhesion assay. Each bar (CFU $\pm \mathrm{SD}$ ) represents the average of three replicates from three independent in vitro assays according to the fitted equations $(n=9)$. Different letters indicate statistical differences (Tukey's test, $p<0.05$ ).

\section{Discussion}

Generally, polysaccharides, cell wall constituents, or storage carbohydrates produced by microalgae are mainly composed of glucose and are called glucans. Their glycosidic linkages vary among the families, classes, and divisions to which they belong. In the haptophytes and diatoms, the common storage polysaccharides are $(1 \rightarrow 3)$ - and/or $(1 \rightarrow 3),(1 \rightarrow 6)-\beta$-glucans [48].

In haptophytes, storage $\beta$-glucans have been investigated only in a few species. Polysaccharides from Isochrysis galbana, Pleurochrysis haptonemofera, and Emiliania huxleyi, belonging 
to class Coccolithophyceae, showed a highly branched $(1 \rightarrow 3),(1 \rightarrow 6)-\beta$-D-glucan with a $(1 \rightarrow 6)$-linked $\beta$-D-Glc $p$ backbone substituted at O-3 by single glucose units or rather short (up to tetrasaccharide) glucooligosaccharide chains [39,49,50], while the polysaccharide from Phaeocystis globose was described as a $(1 \rightarrow 3)$-linked $\beta$-D-glucan substituted at O-6 by glucose residues [51]. In the present research, the glucans isolated from P. gyrans and P. lutheri showed similar structures as expected for species of the same genus. Linear $(1 \rightarrow 3)$-linked $\beta$-glucans were identified in the cold-water-insoluble fraction, while highly branched $\beta$-glucans, constituted by a $(1 \rightarrow 3)$-linked backbone with substitution at O-6, remained in the cold-water-soluble fraction of both species.

In addition to carbohydrates, proteins and lipids are abundant in most haptophytes. Renaud et al. [52] and Ponis et al. [7] found $24.2 \%-32.5 \%$ and 33.8\%-54.3\% protein contents in Coccolithophyceae and Pavlovophyceae species, respectively. Similar contents were found in the alkaline fractions obtained in this research $(30.0 \%-49.1 \%)$. In these fractions, we also identified the glycosides SQG and DGG, as well as free fatty acids. The disruption process of the algal cell wall via the alkali treatment and high temperature used in this research saponified the native acylated forms, namely SQDG (sulfoquinovosyldiacylglycerol), DGDG (digalactosyldiacylglycerol), and TAG (triacylglycerol), generating water-soluble fragments, such as SQG, DGG, and sodium salts of fatty acids [42]. These molecules may interact with proteins, forming stable complexes not eliminated during the dialysis process [53]. Among lipids, the major lipid classes for Pavlova species are TAG and glycolipids. Tatsuzawa and Takizawa [54] reported the following for P. lutheri: 40\% TAG, 25\% MGDG (monogalactosyldiacylglycerol), 10\% SQDG, 8\% DGDG, and 6\% betaine lipids; Eichenberger and Gribi [55] also reported 42\% TAG, 19\% MGDG, 12\% DGDG, 9\% SQDG, $6 \%$ DGTA (diacylglyceryl hydroxymethyl-N,N,N-trimethyl- $\beta$-alanine), and 5\% DGCC (diacylglyceryl carboxyhydroxymethylcholine) for the same species. TAGs are neutral lipids mainly stored in vacuoles within the microalgal cell, while galactolipids and sulfolipids are constituents of chloroplast and extraplastid membranes, respectively [55,56].

Developing alternatives to antibiotics is especially challenging in the area of intestinal infection prevention. The anti-adherence strategy using analog receptors has gained increasing importance. Analog receptors resemble host intestinal receptors and act as decoys via bacteria adsorption, interrupting the adherence process. In this study, an in vitro model was utilized to evaluate the ability of microalgal extracts to specifically adhere Salmonella Typhimurium acting as analog receptor. Fractions with an adhesion capacity were chemically distinct, indicating the presence of different bioactive molecules.

Alkaline fractions that exhibited the greatest adhesion capacity (LA-s, GA-s) did not have a high carbohydrate content (around 16\%) and exhibited heterogeneous monosaccharide composition with absolute content around 5\% glucose, $4 \%$ galactose, and 2.3\% mannose. This observation suggests that adhesins specificity was not entirely a function of the total amount of particular saccharide structures. The Salmonella adhesion is mediated via protein-carbohydrate or a protein-protein interactions [57], thus proteins and glycosides (SQG and DGG) in alkaline fractions could be synergistically cooperating with polysaccharides binding to bacteria through other mechanisms. For Salmonella Typhimurium, the object of this study, protein-protein interactions are mediated by fimbrial and non-fimbrial adhesins and involve the extracellular matrix components of the host cell [58-63]. Several studies reported that milk and colostrum fractions containing proteins ( $\beta$-lactoglobulin, $\alpha$-lactalbumin) and glycopeptides (glycomacropeptide) show anti-adherence properties against Salmonella Typhimurium, Salmonella enteritidis, enteropathogenic Escherichia coli, and enterohemorrhagic E. coli, among others [11,64-66]. Newburg et al. [67] showed that human-milk-derived sulfated glycolipids inhibited the S. Typhimurium pathogenesis in vitro. The high content of proteins observed in the active microalgal extracts and the presence of glycosides suggested that these molecules might also play an important role in the adhesion process.

The aqueous fractions, GW-p or LW-p, with an adhesion capacity similar to the positive control, were composed mainly of $(1 \rightarrow 3)$-linked $\beta$-glucans, and it is possible that the type- 1 adhesins-the most important adhesin found in Salmonella-recognized and bound to glucose present in these fractions. 
Bouckaert et al. [68] determined the binding affinities of the purified FimH lectin from E. coli for several hexoses. The lectin binding site is highly specific for mannose; however, their results showed that FimH can bind to other saccharides, such as fructose and glucose, but their affinity is reduced when compared to mannose. Furthermore, according to Hung et al. [69], the binding-receptor domain interacts with almost all mannose $\mathrm{OH}$ groups, indicating that a glycosidic linkage at $\mathrm{O}-3$ may not be detrimental for the binding since the unit still contains other $\mathrm{OH}$ groups to interact. The fractions mainly composed of highly branched $(1 \rightarrow 3),(1 \rightarrow 6)$-linked $\beta$-glucan, LW-s and GW-s, did not present any potential to adhere to bacteria. This result suggests that unsubstituted O-6 was somehow important for the interaction with $S$. Typhimurium. Hung et al. [69] reported that the O-6 of mannose directly interacts with the backbone of the Asp47 residue, the side-chain oxygen of Asn46 residue, and the $\mathrm{NH}_{2}$ terminal group of the FimH receptor-binding domain, thereby the substitution at O-6 of glucans may have been deleterious for the binding affinity.

Ganner et al. [19] correlated the amount of mannan, glucan, and proteins of yeast cell wall fractions and yeast autolysate products from several strains with their binding capacity to $E$. coli and S. Typhimurium. For Salmonella, the binding affinity was highly correlated with the presence of glucans, whereas the mannan content was important for $E$. coli binding. In accordance with Ganner et al. [19], we believe that many factors influence the binding affinity to these pathogens, together with the mannan and/or glucan content. The polymer three-dimensional structure is also a critical factor for the adhesion process, considering that a pure standardized mannan did not bind to $E$. coli [70], and E. coli with mannose-specific adhesins did not colonize all mannose-containing tissues [71]. Furthermore, the adhesion process might involve other non-specific, hydrophobic, or electrostatic interactions [72]. Adhesion is apparently due to a combination of factors, including saccharide presentation and dimensional structure [71]. It is likely that the 3-linked $\beta$-glucan three-dimensional structure, typical a triple-helix [73], could be favorable to bacteria binding.

The method used in the present study limits us in terms of explaining how the binding between the molecules present in the microalgal fractions and bacteria occurred, or determining whether any unknown mechanism was involved. Nevertheless, our results strengthen the complexity of this subject and it seems clear that binding mechanisms are acting synergistically and/or other mechanisms not yet fully understood or unknown may be involved. Therefore, studies at a molecular level are necessary to elucidate the additional forces that might be involved in the binding mechanism between microalgal extracts and Salmonella Typhimurium. Finally, in vivo experiments with challenged animals could also contribute to validate the adhesion capacity of microalgal molecules and the study of their binding capacity.

\section{Conclusions}

$\beta$-glucans were isolated from aqueous extracts of P. gyrans and P. lutheri. Chemical and spectroscopic analyses showed linear $(1 \rightarrow 3)$-linked $\beta$-D-glucans in the cold-water-precipitated fractions (GW-p, LW-p), whereas the cold-water-soluble fractions (GW-s, LW-s) presented branched $\beta$-D-glucans, which were constituted by a main chain of $(1 \rightarrow 3)$-linked $\beta$-D-Glc $p$ units and highly substituted at O-6 by single $\beta$-D-Glc $p$ units or $(1 \rightarrow 6)$-linked $\beta$-D-Glc $p$ branches. In contrast, the alkaline extracts (GA-s, GA-p, LA-s, LA-p) were mainly composed of proteins, glycosides (SQG, DGG), and free fatty acids.

The use of microtitration-based in vitro bioassays allowed for the identification of extracts from Haptophyta microalgae that specifically adhered to Salmonella Typhimurium, highlighting the potential of these products as an alternative binding matrix for enteropathogens. Additionally, the results clearly indicate that the presence of the $\beta$-glucans and proteins could not be the unique factors responsible for the binding of $S$. Typhimurium to the microalgal extracts; other factors, such as the presence of glycosides, the polymers' three-dimensional structure, and other mechanisms that are still unknown, could be involved in the adhesion process. As such, further studies are necessary to determine the exact binding mechanism between the microalgae bioactive molecules and the enteropathogens. 


\section{Patents}

Noseda, M.D.; Machado, T.W.M.; Noseda, M.E.D.; Rodrigues, J.M. Extrato de microalgas marinhas com capacidade de aderência a bactérias patogênicas. BR102013010798-0.

Supplementary Materials: The following are available online at http:/www.mdpi.com/2076-3417/10/7/2239/s1, Figure S1: 2D NMR COSY spectrum $\left(400 \mathrm{MHz}, \mathrm{Me}_{2} \mathrm{SO}-d_{6}, 70^{\circ} \mathrm{C}\right)$ of GW-s, Figure S2: 2D NMR TOCSY spectrum $\left(400 \mathrm{MHz}, \mathrm{Me}_{2} \mathrm{SO}-d_{6}, 70^{\circ} \mathrm{C}\right.$ ) of GW-s.

Author Contributions: T.W.M.M. and J.M.R. designed and performed the experiments, undertook the analysis and interpretation of data, and wrote the manuscript. T.R.M. assisted in the experiments and data analyses. M.E.R.D. revised all analyses and contributed to the conception and design of the study. M.D.N. conceived, designed, and supervised the study. All authors reviewed and approved the final manuscript.

Funding: This work was supported by the Brazilian agencies: National Council for Scientific and Technological Development (CNPq) (Universal Calls grant numbers: 485980/2012-6, 462414/2014-0); Araucaria Foundation (PRONEX Carboidratos); Coordenação de Aperfeiçoamento de Pessoal de Nível Superior (CAPES), Finance Code 001.

Acknowledgments: M.E.R.D. and M.D.N. are research members of CNPq. T.W.M.M., J.M.R., and T.R.M. acknowledge doctoral/postdoctoral scholarships from CNPq and CAPES. The authors are grateful to Professor Wagner Bonat for help with calculations related to the sigmoidal model and to Grupo Integrado de Aquicultura (GIA-UFPR) for assistance with the microalgae culture.

Conflicts of Interest: The authors declare no conflict of interest.

\section{References}

1. López, Y.; Cepas, V.; Soto, S.M. The marine ecosystem as a source of antibiotics. In Grand Challenges in Marine Biotechnology; Rampelotto, P.H., Trincone, A., Eds.; Springer: Cham, Switzerland, 2018; pp. 3-48. ISBN 978-3-319-69074-2.

2. Chu, W.L. Biotechnological applications of microalgae. IeJSME 2012, 6, S24-S37.

3. Villarruel-López, A.; Ascencio, F.; Nuño, K. Microalgae, a potential natural functional food source-A review. Polish J. Food Nutr. Sci. 2017, 67, 251-264. [CrossRef]

4. Bendif, M.E.; Probert, I.; Hervé, A.; Billard, C.; Goux, D.; Lelong, C.; Cadoret, J.P.; Véron, B. Integrative taxonomy of the Pavlovophyceae (Haptophyta): A reassessment. Protist 2011, 162, 738-761. [CrossRef] [PubMed]

5. Rehberg-Haas, S.; Meyer, S.; Lippemeier, S.; Schulz, C. A comparison among different Pavlova sp. products for cultivation of Brachionus plicatilis. Aquaculture 2015, 435, 424-430. [CrossRef]

6. Haas, S.; Bauer, J.L.; Adakli, A.; Meyer, S.; Lippemeier, S.; Schwarz, K.; Schulz, C. Marine microalgae Pavlova viridis and Nannochloropsis sp. as n-3 PUFA source in diets for juvenile European sea bass (Dicentrarchus labrax L.). J. Appl. Phycol. 2016, 28, 1011-1021. [CrossRef]

7. Ponis, E.; Probert, I.; Véron, B.; Le Coz, J.R.; Mathieu, M.; Robert, R.; Coz, J.R.L.; Mathieu, M.; Robert, R. Nutritional value of six Pavlovophyceae for Crassostrea gigas and Pecten maximus larvae. Aquaculture 2006, 254, 544-553. [CrossRef]

8. Bhalamurugan, G.L.; Valerie, O.; Mark, L. Valuable bioproducts obtained from microalgal biomass and their commercial applications: A review. Environ. Eng. Res. 2018, 23, 229-241. [CrossRef]

9. de Jesus Raposo, M.F.; de Morais, A.M.B.; de Morais, R.M.S.C. Marine polysaccharides from algae with potential biomedical applications. Mar. Drugs 2015, 13, 2967-3028. [CrossRef]

10. Xiao, R.; Zheng, Y. Overview of microalgal extracellular polymeric substances (EPS) and their applications. Biotechnol. Adv. 2016, 34, 1225-1244. [CrossRef]

11. Maldonado-Gomez, M.X.; Lee, H.; Barile, D.; Lu, M.; Hutkins, R.W. Adherence inhibition of enteric pathogens to epithelial cells by bovine colostrum fractions. Int. Dairy J. 2015, 40, 24-32. [CrossRef]

12. Quintero-Villegas, M.I.; Aam, B.B.; Rupnow, J.; Sorlie, M.; Eijsink, V.G.H.; Hutkins, R.W.; Sørlie, M.; Eijsink, V.G.H.; Hutkins, R.W. Adherence inhibition of enteropathogenic Escherichia coli by chitooligosaccharides with specific degrees of acetylation and polymerization. J. Agric. Food Chem. 2013, 61, 2748-2754. [CrossRef] [PubMed]

13. Parkar, S.G.; Redgate, E.L.; Wibisono, R.; Luo, X.; Koh, E.T.H.; Schröder, R. Gut health benefits of kiwifruit pectins: Comparison with commercial functional polysaccharides. J. Funct. Foods 2010, 2, 210-218. [CrossRef] 
14. Gonzalez-Ortiz, G.; Perez, J.F.; Hermes, R.G.; Molist, F.; Jimenez-Diaz, R.; Martin-Orue, S.M. Screening the ability of natural feed ingredients to interfere with the adherence of enterotoxigenic Escherichia coli (ETEC) K88 to the porcine intestinal mucus. Br. J. Nutr. 2014, 111, 633-642. [CrossRef] [PubMed]

15. Rodrigues, J.M.; Duarte, M.E.R.; Noseda, M.D. Modified soybean meal polysaccharide with high adhesion capacity to Salmonella. Int. J. Biol. Macromol. 2019, 139, 1074-1084. [CrossRef] [PubMed]

16. Ofek, I.; Sharon, N.; Abraham, S.N. Bacterial adhesion. In The Prokaryotes; Dworkin, M., Falkow, S., Rosenberg, E., Schleifer, K.H., Stackebrandt, E., Eds.; Springer: Singapore, 2006; Volume 2, pp. 16-31.

17. Laxminarayan, R.; Duse, A.; Wattal, C.; Zaidi, A.K.; Wertheim, H.F.; Sumpradit, N.; Vlieghe, E.; Hara, G.L.; Gould, I.M.; Goossens, H.; et al. Antibiotic resistance-the need for global solutions. Lancet Infect. Dis. 2013, 13, 1057-1098. [CrossRef]

18. Kogan, G.; Kocher, A. Role of yeast cell wall polysaccharides in pig nutrition and health protection. Livest. Sci. 2007, 109, 161-165. [CrossRef]

19. Ganner, A.; Stoiber, C.; Uhlik, J.T.; Dohnal, I.; Schatzmayr, G. Quantitative evaluation of E. coli F4 and Salmonella typhimurium binding capacity of yeast derivatives. AMB Express 2013, 3, 62-69. [CrossRef]

20. Guzman-Murillo, M.A.; Ascencio, F. Anti-adhesive activity of sulphated exopolysaccharides of microalgae on attachment of red sore disease-associated bacteria and Helicobacter pylori to tissue culture cells. Lett. Appl. Microbiol. 2000, 30, 473-478. [CrossRef]

21. Loke, M.F.; Lui, S.Y.; Ng, B.L.; Gong, M.; Ho, B. Antiadhesive property of microalgal polysaccharide extract on the binding of Helicobacter pylori to gastric mucin. FEMS Immunol. Med. Microbiol. 2007, 50, $231-238$. [CrossRef]

22. Guillard, R.R.L. Culture of phytoplankton for feeding marine invertebrates. In Culture of Marine Invertebrate Animals; Smith, W.L., Chanley, M.H., Eds.; Plenum Press: New York, NY, USA, 1975; pp. $29-60$. ISBN 978-1-4615-8714-9.

23. Gorin, P.A.J.; Iacomini, M. Structural diversity of D-galacto-D-mannan components isolated from lichens having Ascomycetous mycosymbionts. Carbohydr. Res. 1985, 142, 253-261. [CrossRef]

24. Lowry, O.H.; Rosebrough, N.J.; Farr, A.L.; Randall, R.J. Protein measurement with the Folin phenol reagent. J. Biol. Chem. 1951, 193, 265-275. [PubMed]

25. DuBois, M.; Gilles, K.A.; Hamilton, J.K.; Rebers, P.A.; Smith, F. Colorimetric method for determination of sugars and related substances. Anal. Chem. 1956, 28, 350-356. [CrossRef]

26. Jansson, P.E.; Kenne, L.; Liedgren, H.; Lindberg, B.; Lönngren, J. A practical guide to the methylation analysis of carbohydrates. Chem. Commun. Univ. Stock. 1976, 8, 1-75.

27. Ciucanu, I.; Kerek, F. A simple and rapid method for the permethylation of carbohydrates. Carbohydr. Res. 1984, 131, 209-217. [CrossRef]

28. Bao, X.; Liu, C.; Fang, J.; Li, X. Structural and immunological studies of a major polysaccharide from spores of Ganoderma lucidum (Fr.) Karst. Carbohydr. Res. 2001, 332, 67-74. [CrossRef]

29. Sassaki, G.L.; Gorin, P.A.J.; Souza, L.M.; Czelusniak, P.A.; Iacomini, M. Rapid synthesis of partially O-methylated alditol acetate standards for GC-MS: Some relative activities of hydroxyl groups of methyl glycopyranosides on Purdie methylation. Carbohydr. Res. 2005, 340, 731-739. [CrossRef]

30. Ascêncio, S.D.; Orsato, A.; França, R.A.; Duarte, M.E.R.; Noseda, M.D. Complete ${ }^{1} \mathrm{H}$ and ${ }^{13} \mathrm{C}$ NMR assignment of digeneaside, a low-molecular-mass carbohydrate produced by red seaweeds. Carbohydr. Res. 2006, 341, 677-682. [CrossRef]

31. Becker, P.M.; Galletti, S.; Roubos-van den Hil, P.J.; van Wikselaar, P.G. Validation of growth as measurand for bacterial adhesion to food and feed ingredients. J. Appl. Microbiol. 2007, 103, 2686-2696. [CrossRef]

32. Ganner, A.; Stoiber, C.; Wieder, D.; Schatzmayr, G. Quantitative in vitro assay to evaluate the capability of yeast cell wall fractions from Trichosporon mycotoxinivorans to selectively bind gram negative pathogens. J. Microbiol. Methods 2010, 83, 168-174. [CrossRef]

33. Batista, A.P.; Gouveia, L.; Bandarra, N.M.; Franco, J.M.; Raymundo, A. Comparison of microalgal biomass profiles as novel functional ingredient for food products. Algal Res. 2013, 2, 164-173. [CrossRef]

34. Fernandes, T.; Fernandes, I.; Andrade, C.A.P.; Ferreira, A.; Cordeiro, N. Marine microalgae monosaccharide fluctuations as a stress response to nutrients inputs. Algal Res. 2017, 24, 340-346. [CrossRef]

35. Marcilla, A.; Gómez-Siurana, A.; Gomis, C.; Chápuli, E.; Catalá, M.C.; Valdés, F.J. Characterization of microalgal species through TGA/FTIR analysis: Application to Nannochloropsis sp. Thermochim. Acta 2009, 484, 41-47. [CrossRef] 
36. Ponder, G.R.; Richards, G.N.; Stevenson, T.T. Influence of linkage position and orientation in pyrolysis of polysaccharides: A study of several glucans. J. Anal. Appl. Pyrolysis 1992, 22, 217-229. [CrossRef]

37. Leng, E.; Costa, M.; Peng, Y.; Zhang, Y.; Gong, X.; Zheng, A.; Huang, Y.; Xu, M. Role of different chain end types in pyrolysis of glucose-based anhydro-sugars and oligosaccharides. Fuel 2018, 234, 738-745. [CrossRef]

38. Dobruchowska, J.M.; Jonsson, J.O.; Fridjonsson, O.H.; Aevarsson, A.; Kristjansson, J.K.; Altenbuchner, J.; Watzlawick, H.; Gerwig, G.J.; Dijkhuizen, L.; Kamerling, J.P.; et al. Modification of linear ( $\beta$ 1 $\rightarrow 3$ )-linked gluco-oligosaccharides with a novel recombinant beta-glucosyltransferase (trans-beta-glucosidase) enzyme from Bradyrhizobium diazoefficiens. Glycobiology 2016, 26, 1157-1170. [PubMed]

39. Sadovskaya, I.; Souissi, A.; Souissi, S.; Grard, T.; Lencel, P.; Greene, C.M.; Duin, S.; Dmitrenok, P.S.; Chizhov, A.O.; Shashkov, A.S.; et al. Chemical structure and biological activity of a highly branched $(1 \rightarrow 3,1 \rightarrow 6)-\beta-D-g l u c a n$ from Isochrysis galbana. Carbohydr. Polym. 2014, 111, 139-148. [CrossRef] [PubMed]

40. Kono, H.; Kondo, N.; Hirabayashi, K.; Ogata, M.; Totani, K.; Ikematsu, S.; Osada, M. NMR spectroscopic structural characterization of a water-soluble beta-(1 $\rightarrow 3,1 \rightarrow 6)$-glucan from Aureobasidium pullulans. Carbohydr. Polym. 2017, 174, 876-886. [CrossRef]

41. Lowman, D.W.; West, L.J.; Bearden, D.W.; Wempe, M.F.; Power, T.D.; Ensley, H.E.; Haynes, K.; Williams, D.L.; Kruppa, M.D. New Insights into the structure of $(1 \rightarrow 3,1 \rightarrow 6)-\beta$-D-Glucan side chains in the Candida glabrata cell wall. PLoS ONE 2011, 6, e27614. [CrossRef]

42. Sassaki, G.L.; Machado, M.J.; Tischer, C.A.; Gorin, P.A.J.; Iacomini, M. Glycosyldiacylglycerolipids from the lichen Dictyonema glabratum. J. Nat. Prod. 1999, 62, 844-847. [CrossRef]

43. de Souza, L.M.; Iacomini, M.; Gorin, P.A.J.; Sari, R.S.; Haddad, M.A.; Sassaki, G.L. Glyco- and sphingophosphonolipids from the medusa Phyllorhiza punctata: NMR and ESI-MS/MS fingerprints. Chem. Phys. Lipids 2007, 145, 85-96. [CrossRef]

44. Wang, H.; Li, Y.L.; Shen, W.Z.; Rui, W.; Ma, X.J.; Cen, Y.Z. Antiviral activity of a sulfoquinovosyldiacylglycerol (SQDG) compound isolated from the green alga Caulerpa racemosa. Bot. Mar. 2007, 50, 185-190. [CrossRef]

45. Almoselhy, R.I.M.; Allam, M.H.; El-Kalyoubi, M.H.; El-Sharkawy, A.A. 1H NMR spectral analysis as a new aspect to evaluate the stability of some edible oils. Ann. Agric. Sci. 2014, 59, 201-206. [CrossRef]

46. Cavanagh, J.; Fairbrother, W.J.; Palmer, A.G.; Rance, M.; Skelton, N.J.B. Sequential assignment, structure determination, and other applications. In Protein NMR Spectroscopy: Principles and Practice; Cavanagh, J., Fairbrother, W.J., Palmer, A.G., Rance, M., Skelton, N.J.B., Eds.; Academic Press: Burlington, VT, USA, 2007; pp. 781-817. ISBN 978-0-12-164491-8.

47. Ma, L.; Yang, Y.; Yao, J.; Shao, Z.; Huang, Y.; Chen, X. Selective chemical modification of soy protein for a tough and applicable plant protein-based material. J. Mater. Chem. B 2015, 3, 5241-5248. [CrossRef]

48. Myklestad, S.M.; Granum, E. Biology of $(1,3)-\beta$-Glucans and related glucans in protozoans and chromistans. In Chemistry, Biochemistry, and Biology of 1-3 $\beta$ Glucans and Related Polysaccharides; Bacic, A., Fincher, G.B., Stone, B.A., Eds.; Academic Press: San Diego, CA, USA, 2009; pp. 353-385. ISBN 978-0-12-373971-1.

49. Hirokawa, Y.; Fujiwara, S.; Suzuki, M.; Akiyama, T.; Sakamoto, M.; Kobayashi, S.; Tsuzuki, M. Structural and physiological studies on the storage beta-polyglucan of haptophyte Pleurochrysis haptonemofera. Planta 2008, 227, 589-599. [CrossRef] [PubMed]

50. Varum, K.M.; Kvam, B.J.; Myklestad, S.; Paulsen, B.S. Structure of a food-reserve $\beta$-D-glucan produced by the haptophyte alga Emiliania huxleyi (Lohmann) Hay and Mohler. Carbohydr. Res. 1986, 152, 243-248. [CrossRef]

51. Janse, I.; van Rijssel, M.; van Hall, P.J.; Gerwig, G.J.; Gottschal, J.C.; Prins, R.A. The storage glucan of Phaeocystis globosa (Prymesiophyceae) cells. J. Phycol. 1996, 32, 382-387. [CrossRef]

52. Renaud, S.M.; Van Thinh, L.; Parry, D.L. The gross chemical composition and fatty acid composition of 18 species of tropical Australian microalgae for possible use in mariculture. Aquaculture 1999, 170, 147-159. [CrossRef]

53. Mauer, L. Heat Treatment for Food Proteins. In Encyclopedia of Food Sciences and Nutrition; Caballero, B., Trug, L., Finglas, P.M., Eds.; Academic Press: Oxford, UK, 2003; pp. 4868-4872. ISBN 978-0-12-227055-0.

54. Tatsuzawa, H.; Takizawa, E. Changes in lipid and fatty acid composition of Pavlova lutheri. Phytochemistry 1995, 40, 397-400. [CrossRef]

55. Eichenberger, W.; Gribi, C. Lipids of Pavlova lutheri: Cellular site and metabolic role of DGCC. Phytochemistry 1997, 45, 1561-1567. [CrossRef]

56. Thompson, G.A. Lipids and membrane function in green algae. Biochim. Biophys. Acta Lipids Lipid Metab. 1996, 1302, 17-45. [CrossRef] 
57. Shoaf-Sweeney, K.D.; Hutkins, R.W. Chapter 2 Adherence, anti-adherence, and oligosaccharides: Preventing pathogens from sticking to the host. Adv. Food Nutr. Res. 2008, 55, 101-161.

58. Romling, U.; Bian, Z.; Hammar, M.; Sierralta, W.D.; Normark, S. Curli fibers are highly conserved between Salmonella typhimurium and Escherichia coli with respect to operon structure and regulation. J. Bacteriol. 1998, 180, 722-731. [CrossRef] [PubMed]

59. Wagner, C.; Barlag, B.; Gerlach, R.G.; Deiwick, J.; Hensel, M. The Salmonella enterica giant adhesin SiiE binds to polarized epithelial cells in a lectin-like manner. Cell. Microbiol. 2014, 16, 962-975. [CrossRef] [PubMed]

60. Griessl, M.H.; Schmid, B.; Kassler, K.; Braunsmann, C.; Ritter, R.; Barlag, B.; Stierhof, Y.-D.; Sturm, K.U.; Danzer, C.; Wagner, C.; et al. Structural insight into the giant $\mathrm{Ca}^{2+}$-Binding Adhesin SiiE: Implications for the adhesion of Salmonella enterica to polarized epithelial cells. Structure 2013, 21, 741-752. [CrossRef] [PubMed]

61. Dorsey, C.W.; Laarakker, M.C.; Humphries, A.D.; Weening, E.H.; Bäumler, A.J. Salmonella enterica serotype Typhimurium MisL is an intestinal colonization factor that binds fibronectin. Mol. Microbiol. 2005, 57, 196-211. [CrossRef]

62. Weimer, B.C.; Chen, P.; Desai, P.T.; Chen, D.; Shah, J. Whole cell cross-linking to discover host-microbe protein cognate receptor/ligand pairs. Front. Microbiol. 2018, 9, 1585. [CrossRef]

63. Chowdhury, S.M.; Shi, L.; Yoon, H.; Ansong, C.; Rommereim, L.M.; Norbeck, A.D.; Auberry, K.J.; Moore, R.J.; Adkins, J.N.; Heffron, F.; et al. A method for investigating protein-protein interactions related to Salmonella Typhimurium pathogenesis. J. Proteome Res. 2009, 8, 1504-1514. [CrossRef]

64. Brück, W.M.; Kelleher, S.L.; Gibson, G.R.; Graverholt, G.; Lonnerdal, B.L. The effects of a-lactalbumin and glycomacropeptide on the association of CaCo-2 cells by enteropathogenic Escherichia coli, Salmonella typhimurium and Shigella flexneri. FEMS Microbiol. Lett. 2006, 259, 158-162. [CrossRef]

65. Nakajima, K.; Tamura, N.; Kobayashi-Hattori, K.; Yoshida, T.; Hara-Kudo, Y.; Ikedo, M.; Sugita-Konishi, Y.; Hattori, M. Prevention of intestinal infection by glycomacropeptide. Biosci. Biotechnol. Biochem. 2005, 69, 2294-2301. [CrossRef]

66. Ouwehand, A.C.; Salminen, S.J.; Skurnik, M.; Conway, P.L. Inhibition of pathogen adhesion by $\beta$-lactoglobulin. Int. Dairy J. 1997, 7, 685-692. [CrossRef]

67. Newburg, D.S.; McCormick, B.; Chaturvedi, P.; Siber, A.M.; Warren, C.D. Inhibition of Salmonella typhimurium by human milk sulfatides. Pediatr. Res. 1999, 45, 116. [CrossRef]

68. Bouckaert, J.; Berglund, J.; Schembri, M.; De Genst, E.; Cools, L.; Wuhrer, M.; Hung, C.S.; Pinkner, J.; Slattegard, R.; Zavialov, A.; et al. Receptor binding studies disclose a novel class of high-affinity inhibitors of the Escherichia coli FimH adhesin. Mol. Microbiol. 2005, 55, 441-455. [CrossRef] [PubMed]

69. Hung, C.S.; Bouckaert, J.; Hung, D.; Pinkner, J.; Widberg, C.; DeFusco, A.; Auguste, C.G.; Strouse, R.; Langermann, S.; Waksman, G.; et al. Structural basis of tropism of Escherichia coli to the bladder during urinary tract infection. Mol. Microbiol. 2002, 44, 903-915. [CrossRef] [PubMed]

70. Ganner, A.; Fink, L.; Schatzmayr, G. Quantitative in vitro assay to evaluate yeast products concerning their binding activity of enteropathogenic bacteria. J. Anim. Sci. 2008, 86, 54.

71. Ofek, I.; Doyle, R.J. Principles of Bacterial Adhesion. In Bacterial Adhesion to Cells and Tissues; Ofek, I., Doyle, R.J., Eds.; Springer: Boston, MA, USA, 1994; pp. 1-15. ISBN 978-1-4684-6435-1.

72. Ofek, I.; Hasty, D.L.; Sharon, N. Anti-adhesion therapy of bacterial diseases: Prospects and problems. FEMS Immunol. Med. Microbiol. 2003, 38, 181-191. [CrossRef]

73. Sletmoen, M.; Stokke, B.T. Higher order structure of $(1,3)-\beta-D-G l u c a n s$ and its influence on their biological activities and complexation abilities. Biopolymers 2008, 89, 310-321. [CrossRef]

(C) 2020 by the authors. Licensee MDPI, Basel, Switzerland. This article is an open access article distributed under the terms and conditions of the Creative Commons Attribution (CC BY) license (http://creativecommons.org/licenses/by/4.0/). 